\title{
Re(de)fining the Orthographic Neighborhood: The Role of Addition and Deletion Neighbors in Lexical Decision and Reading
}

\author{
Colin J. Davis \\ Royal Holloway, University of London
}

\author{
Manuel Perea and Joana Acha \\ Universitat de València
}

\begin{abstract}
The influence of addition and deletion neighbors on visual word identification was investigated in four experiments. Experiments 1 and 2 used Spanish stimuli. In Experiment 1, lexical decision latencies were slower and less accurate for words and nonwords with higher-frequency deletion neighbors (e.g., jugar in juzgar), relative to control stimuli. Experiment 2 showed a similar interference effect for words and nonwords with higher-frequency addition neighbors (e.g., conejo, which has the addition neighbor consejo), relative to control stimuli. Experiment 3 replicated this addition neighbor interference effect in a lexical decision experiment with English stimuli. Across all three experiments, interference effects were always evident for addition/deletion neighbors with word-outer overlap, usually present for those with word-initial overlap, but never present for those with word-final overlap. Experiment 4 replicated the addition/deletion neighbor inhibitory effects in a Spanish sentence reading task in which the participants' eye movements were monitored. These findings suggest that conventional orthographic neighborhood metrics should be redefined. In addition to its methodological implications, this conclusion has significant theoretical implications for input coding schemes and the mechanisms underlying word recognition.
\end{abstract}

Keywords: visual word recognition, lexical inhibition, neighborhood effects, orthographic input coding, SOLAR model

In the past decade, cracking the orthographic code has become a key question for researchers in visual word recognition and reading (see Grainger, 2008, for a recent review). The origins of this quest can be traced 3 decades ago, when Coltheart, Davelaar, Jonasson, and Besner (1977) reported an experiment that has come to be considered a classic study in the field of visual word identification. To investigate lexical access procedures, Coltheart and colleagues manipulated an orthographic similarity metric that they labeled " $N$ ". The $N$ metric had previously been suggested by Landauer and Streeter (1973) as a measure of the number of close "neighbors" of a stimulus, and was computed by counting the number of words that can be created by changing a single letter of the stimulus. For example, $N=10$ for the word river (which has an orthographic neighborhood that includes the words diver, liver, rover, rider, and rivet), whereas $N=1$ for the word drive, as only a single word (drove) can be formed by substituting a single letter. In a lexical decision task, Coltheart et al. (1977) found that $N$ had no effect on the latency of "Yes" responses, but that "No" responses were significantly slower to large- $N$ nonwords than to small $-N$ nonwords. This was interpreted as evidence against a serial search model and in favor of a parallel access model like

Colin J. Davis, Royal Holloway, University of London; Manuel Perea, Universitat de València; Joana Acha, Universitat de València.

This research was partially supported by a Grant from the Spanish Ministry of Education and Science (PSI2008-04069/PSIC) to Manuel Perea. Joana Acha was the recipient of a post-graduate grant from the Basque Government.

Correspondence concerning this article may be addressed to Colin Davis, Department of Psychology, Royal Holloway, University of London, Egham, Surrey TW20 0EX, UK. E-mail: c.davis@rhul.ac.uk
Morton's (1970) logogen model. It was argued that fixating a written word leads to the automatic activation of its neighbors, and that this lexical activation made it harder to reject large- $N$ nonwords than small- $N$ nonwords.

In the years since Coltheart et al.'s (1977) study, orthographic neighborhood effects have been revisited many times, and a wealth of research has examined the effect on stimulus recognition of both the size of the similarity neighborhood and the frequency of the words contained in the neighborhood (for reviews, see Andrews, 1997 and Grainger, 2008). The reason for this interest is that patterns of lexical similarity provide insights into the organization of lexical and orthographic knowledge, and neighborhood effects provide critical evidence about lexical retrieval and selection processes. Virtually all of this research has adopted the definition of orthographic neighbors that was employed by Landauer and Streeter (1973) and Coltheart et al. (1977). In recent times, however, it has become increasingly clear that the $N$ metric is a rather crude measure of the size of a word's neighborhood. Indeed, it seems possible that this measure has now outlived its usefulness, and that an alternative measure of neighborhood density is required.

A common, but somewhat naïve, view of the $N$ metric is that it represents a count of all of the words that are sufficiently similar to an input stimulus to become activated when this stimulus is presented. However, experimental evidence makes it clear that a full picture of the orthographic neighborhood of a letter string is not found simply by counting the number of words formed by letter substitutions (we will use the term substitution neighbor for this type of neighbor, where $N$ is the total number of substitution neighbors [SNs] of a given word). 
One form of orthographic relationship that is not captured by the $N$ metric is the similarity between transposition neighbors (TNs). These are pairs of letter strings that are identical save for the transposition of two adjacent letters; for example, the word trail is a transposition neighbor of the word trial. Studies using both unprimed lexical decision and naming tasks have shown inhibitory effects of TN similarity, for example, words like trail are classified more slowly (and/or with a higher error rate) than control words like drain (Andrews, 1996; Chambers, 1979; Davis \& Andrews, 2001). Furthermore, form priming studies have shown that TN nonword primes produce greater facilitation than substitution neighbor primes (e.g., Forster, Davis, Schoknecht, \& Carter, 1987; Perea \& Lupker, 2003; Schoonbaert \& Grainger, 2004; see also Johnson, Perea, \& Rayner, 2007, for eye-movement evidence), and that TN nonword primes are effective even when the transposed letters are not adjacent (Perea \& Lupker, 2004; see also Lupker, Perea, \& Davis, 1998; Perea, Duñabeitia, \& Carreiras, 2008; Perea \& Carreiras, 2006a, 2006b, 2006c). These effects of TN similarity suggest that the definition of a letter string's orthographic similarity neighborhood needs to be broadened to include not just words that can be formed by letter substitution but also words that can be formed by letter transpositions.

Another type of similarity that has recently been studied is one that combines letter transpositions and substitutions (Davis \& Bowers, 2004, 2006). For example, pairs like trawl and trial contain four common letters (like SNs such as trawl and trail), but one of the common letters (in this case, the letter $a$ ) occurs in a different position in the two words. In effect, pairs like this consist of a letter transposition followed by a substitution of one of the transposed letters. Davis and Bowers (2004) coined the term "neighbors once-removed" (N1R) to describe this form of similarity. They reported evidence from the illusory word (or "letter migration") paradigm showing that N1R pairs are more similar than pairs involving two letter substitutions. That is, the common letter $A$ in trial and trawl contributes to the perceptual similarity of these strings, even though it occurs in different positions in the two cases. More recently, Davis and Bowers (2006) have reported evidence from both the illusory word paradigm and the masked priming lexical decision paradigm that replicates the above finding whereas also showing that N1R pairs are less similar than SN pairs, a result that has important implications for theories of orthographic input coding.

\section{Addition and Deletion Neighbors}

Each of the similarity relationships discussed so far (substitution neighbors, transposition neighbors, and neighbors once-removed) involves pairs of letter strings that are of equal length. However, what about the similarity of letter strings that contain many common letters, but which differ in length (e.g., drive-dive)? We define an addition neighbor (AN) of a word to be a letter string that involves the addition of a single letter (in any position) to that word, and a deletion neighbor (DN) of a word to be a letter string that differs from that word by the deletion of a single letter. For example, the words drivel and derive are addition neighbors of drive, and the word dive is a $\mathrm{DN}$ of the word drive. This raises the following question: Are DNs and ANs also part of a word's similarity neighborhood? (e.g., should the neighborhood of the word drive consist of not just the single word drove, but also the words dive, drivel, driver, and derive?). This question is of interest for a variety of reasons, both with regard to theoretical issues (e.g., what is the input code used to represent words?; are the effects of similarity facilitatory or inhibitory?; how are similar words of different lengths distinguished?) and methodologic questions (e.g., how should neighbors be counted when controlling stimuli in psycholinguistic experiments?). What we should also note is that the proposed distinction is similar to the definition of a word neighbor in auditory word recognition (e.g., Goldinger, Luce, \& Pisoni 1989), in which the neighborhood has been defined not just via the "substitution" rule (i.e., a replaced phoneme) keeping the rest the same (as in the Coltheart et al. definition), but also via the "add or delete" rule. That is, a lexical entry counts as similar to another (i.e., a "phonologic neighbor") if it can be changed into the other by adding, subtracting, or changing one phoneme (i.e., that, at, bat, cot, and cap would be phonologic neighbors of cat).

One important reason for being interested in the perceptual similarity of DNs and ANs is that this is a critical issue for the input coding scheme of any computational model of visual word recognition. Finding that a word like drive is perceptually similar to ANs like derive and drivel would pose a problem for standard methods of input coding, such as the schemes used in the interactive-activation (IA) model and its extensions (e.g., dualroute cascaded [DRC] model, Coltheart, Rastle, Perry, Ziegler, \& Langdon, 2001; multiple read-out model, Grainger \& Jacobs, 1996; Jacobs, Rey, Ziegler, \& Grainger, 1998; the lexical route in the CDP + model, Perry, Ziegler, \& Zorzi, 2007). According to coding schemes based on absolute position, drive and derive share only one unit (the initial letter $d$, i.e., this pair is no more similar than drive and dough in the coding scheme of the DRC model, Coltheart et al., 2001). Thus, evidence supporting the perceptual similarity of DNs and ANs requires researchers to use an alternative type of coding scheme. Indeed, there are a number of recently proposed models that predict the perceptual similarity of letter strings to their ANs and DNs (e.g., SOLAR model, Davis, 1999, 2004; SERIOL model, Whitney, 2001; overlap model, Gómez, Ratcliff, \& Perea, in press). (We defer a discussion of these models until the General Discussion.)

A second reason for being interested in the perceptual similarity of DNs and ANs is that this type of similarity offers an insight into the role of length sensitivity in visual word identification. It is conceivable that readers employ some form of length sensitive mechanism to constrain the set of potential word candidates that are activated during word identification. For example, if the identification system has access to the information that an input stimulus like drive has five letters, it could automatically exclude competitors like dive, derive, and drivel, narrowing down the set of potential candidates to words like drive and drove. It has been suggested that such a mechanism could explain the common tendency of patients with neglect dyslexia to preserve word length (e.g., reporting pillow as yellow, rather than, say, low, despite having a tendency to neglect the initial portion of a word; Tegner \& Levander, 1993). A mechanism of this sort has also been proposed to explain data from normal readers. Smith, Jordan, and Sharma (1991) described an extension of the IA model that incorporates "length" units that are stimulated when word units of a particular letter length are active, and showed how this model could account for length-dependent masking phenomena. Finding evidence that both ANs and DNs are perceptually similar to the 
words they are derived from would rule out a strict length-sensitive mechanism.

A third reason for being interested in the perceptual similarity of DNs and ANs is purely methodologic. It is common practice to control $N$ in experiments investigating other psycholinguistic variables. However, if the similarity neighborhood of a letter string includes words of different lengths, using $N$ may be an inappropriate way to match stimuli on similarity to other words. Similarly, some effects interact strongly with neighborhood density, such as the effects of masked form priming (e.g., Forster et al., 1987; Perea \& Rosa, 2000). Thus, it is relevant to know whether DNs and ANs should be counted when selecting target stimuli for masked priming experiments.

\section{Previous Empirical Evidence Pertaining to DNs and ANs}

There is some empirical evidence that suggests that DNs and possibly ANs are partially activated during word recognition. de Moor and Brysbaert (2000) reported a lexical decision experiment that showed an inhibitory effect of masked word primes that were DNs (e.g., rail-TRAIL; in Dutch, over-ROVER) or ANs (e.g., crown-CROW; in Dutch, oever-EVER) of the target words. This suggests that target word identification can be delayed by competition with different-length neighbors. However, it is possible that competition is specific to the priming paradigm (in which the DNs and ANs are actually presented), and is not reflective of the identification process in normal reading.

Schoonbaert and Grainger (2004) found a facilitatory masked priming effect in a lexical decision task, relative to an unrelated priming condition, when the related primes were nonwords formed by removing a single letter of the target (e.g., mircle-MIRACLE). Using the same experimental paradigm, Van Assche and Grainger (2006) found a facilitatory masked priming effect when the related primes were nonwords formed by adding a single letter to the target (e.g., mirancle-MIRACLE; see also Welvaert, Farioli, \& Grainger, 2008). Taken together, these results suggest that the primes preactivated their addition/deletion neighbors. Once again, though, some caution is needed in generalizing from a priming paradigm to draw conclusions about whether different-length neighbors are automatically activated. The fact that DN nonword primes facilitate decisions to AN targets does not necessarily imply that a DN like drive influences the time taken to access derive in unprimed presentations (see Andrews, 1996; Perea \& Rosa, 2000).

A recent experiment by Bowers, Davis, and Hanley (2005a) observed interference effects from DNs in semantic categorization. For example, participants took longer to respond "No" when asked to decide whether the word apex (which has the DN ape) refers to a type of animal than to decide whether apex refers to a type of vehicle. This interference suggests that DNs were processed to the level of meaning, and that these DNs impaired performance when they required a different response than the presented word. A second experiment reported by Bowers et al. (2005a) showed a similar interference effect from words that were longer than the target. For example, participants took longer to decide that seep (which has the AN sheep) was not a type of animal than to decide that it was not a type of vehicle. Likewise, participants took longer to decide that pane (which has the AN plane) was not a type of vehicle than to decide that it was not a type of animal. Thus, the results of Bowers et al. suggest that both ANs and DNs are automatically activated during visual word identification.

Davis and Taft (2005) have recently reported two lexical decision experiments that provide further evidence for the automatic activation of DNs. The first experiment showed that nonwords with DNs were classified more slowly and less accurately than control nonwords. The second experiment showed that words with DNs (e.g., tablet, drown) were classified more slowly and less accurately than matched control words (e.g., tumble, clown).

\section{Position of Overlap}

Evidence that some addition or deletion neighbors are automatically activated during word identification need not imply that all such neighbors become activated. It is possible to distinguish between three different positions of overlap among addition and deletion neighbors: initial overlap (e.g., drawl-draw), final overlap (e.g., beach-each), and outer overlap (e.g., width-with). This distinction is theoretically important for comparing orthographic input coding schemes, and for evaluating the importance of exterior letters. As noted above, a position-specific ("slot") coding scheme based on absolute position (such as DRC's) predicts that outer overlap pairs like drive and derive are relatively dissimilar. It also predicts that final overlap pairs like beach and each are not at all similar, because their common letters are misaligned. However, this type of scheme predicts that initial overlap pairs like drive and drivel are very similar (this pair shares five out of six letter units). Thus, this type of coding scheme can predict AN and DN similarity, but only for neighbors with initial overlap.

A different type of slot-coding scheme was proposed by Jacobs et al. (1998), according to which specific units code the outer letters of a word and the remaining letters are assigned to units from the outside-in (e.g., width would be coded as $w_{I}, i_{I+1}, d_{I+2}$, $t_{F-1}, h_{F}$, where the subscripts $I$ and $F$ denote the initial and final letters, respectively). This type of scheme predicts that outer overlap pairs like width and with are relatively similar, sharing four out of five letter units $\left(w_{I}, i_{I+1}, t_{F-1}\right.$, and $\left.h_{F}\right)$. However, it predicts that pairs with word-initial or word-final overlap are relatively dissimilar (e.g., drawl and draw share only two out of five letter units, as do beach and each, and hence the match is no greater than that between drawl and drink or beach and witch).

A third type of slot-coding scheme has been proposed by Zorzi, Houghton, and Butterworth (1998) and Harm and Seidenberg (1999). This scheme contains eight letter slots (enough to code any monosyllabic word in English), where the first vowel of a word is always coded by Slot 4 , and letters are assigned to other slots based on their position relative to the vowel (note that the maximum number of consonants that can occur before a vowel in a legal English monosyllable is three, e.g., str). This vowel-centered scheme predicts that ANs and DNs should be similar for initial overlap and final overlap pairs, but not for outer overlap pairs. For example, width and with share only the vowel and the initial consonant (the postvocalic consonants are misaligned), which implies that this pair is no more similar than width and wing. Likewise, fright and freight share only three out of six common units (the consonants are aligned, but the vowel graphemes are misaligned). In summary, then, different types of coding schemes make different predictions about the effect of position of overlap, even within the class of slot-coding schemes. 
To date, the evidence concerning position of overlap is inconclusive. The interference effect reported by Davis and Taft (2005) did not interact with position of overlap, although the magnitude of the effect was numerically greatest for the outer overlap condition (44 ms), somewhat reduced for the initial overlap condition (28 $\mathrm{ms}$ ), and negligible for the final overlap condition (9 ms). Likewise, the interference effect reported by Bowers et al. (2005a) did not interact with position of overlap, but there was some indication that the effect was stronger for initial and outer overlap pairs than for final overlap pairs (in Experiment 2, the former two conditions both showed interference effects of over $40 \mathrm{~ms}$, whereas the latter condition showed an interference effect of only $14 \mathrm{~ms}$ ). An important goal of the present paper is to provide more conclusive evidence regarding this issue.

\section{Are Similarity Effects Facilitatory or Inhibitory?}

Another issue related to neighborhood effects that has aroused considerable interest is whether neighbors exert a facilitatory or an inhibitory influence on word identification. The interference effect reported by Bowers et al. (2005a) does not address this issue, because this effect reflects coactivation at the semantic level, and does not indicate whether there is inhibition or facilitation between neighbors at the level of the orthographic lexicon. However, the DN interference effect found by Davis and Taft (2005) suggests that higher frequency DNs inhibit "Yes" responses at a lexical level. This is consistent with evidence that higher-frequency TNs inhibit "Yes" responses to word stimuli in unprimed naming (Davis \& Andrews, 2001), and that higher-frequency substitution neighbors inhibit "Yes" responses to word stimuli in unprimed lexical decision (e.g., Grainger \& Jacobs, 1996; Grainger, O’Regan, Jacobs, \& Segui, 1989, 1992; Huntsman \& Lima, 1996; Perea \& Pollatsek, 1998). Taken together, this pattern supports the prediction of competitive network models in which identification is achieved through competition among lexical representations in the similarity neighborhood of the input stimulus. Nevertheless, a number of experiments have failed to find inhibitory effects of higher-frequency substitution neighbors, and in some cases have observed facilitatory effects (e.g., Forster \& Shen, 1996; Sears, Hino, \& Lupker, 1995; Siakaluk, Sears, \& Lupker, 2002). Furthermore, the majority of experiments investigating $N$ effects have observed facilitatory effects of this variable on lexical decisions to words (Andrews, 1997; Pollatsek, Perea, \& Binder, 1999). ${ }^{1}$

\section{The Experiments}

In summary, there is good reason to think that the $N$ metric excludes some of the words that should be included in the perceptual similarity neighborhood of a letter string. There is already some evidence supporting the perceptual similarity of addition and deletion neighbors. The goal of the experiments presented here was to provide further evidence related to this issue, from a language in which these effects have not previously been tested. A further goal was to systematically examine the effect of position of overlap. The evidence to date with respect to this factor is inconclusive, and a better characterization of the effect of position of overlap would help to strongly constrain models of orthographic input coding. Finally, the experiments aimed to provide further evidence for the hypothesis that neighbors exert an inhibitory, rather than a facilitatory, effect on visual word identification. Four experiments are reported: Experiment 1 focused on DNs, whereas Experiments 2 and 3 focused on ANs in a single presentation lexical decision task. Each of these experiments investigated the effect of the position of overlap between neighbors of different length.

Finally, Experiment 4 examined the effects of DNs and ANs in normal silent reading while the participants' eye movements were monitored. The rationale of including a silent reading experiment is that if neighborhood effects from ANs or DNs are found (i.e., if the fixation times on words in the target word region are affected by the presence of ANs or DNs), then one has clear evidence that neighborhood effects are not restricted to laboratory word identification tasks but are actually influencing reading (see Perea \& Pollatsek, 1998). That is, the idea is that if the AN/DN neighbor has a higher frequency in the language than the word actually presented, it seems plausible that activation of this higher frequency neighbor could compete with the activation of the "correct" lexical entry and produce inhibitory effects in reading. Furthermore, the use of eye-movement techniques allows us to shed light on the time course of these neighborhood effects, the reason being that the series of eye movements offers a sequential record of the processing of the text material. Indeed, there is evidence of an inhibitory effect of "neighborhood frequency" in normal silent reading when using substitution neighbors (e.g., spice because of space; Perea \& Pollatsek, 1998; Pollatsek, Perea, \& Binder, 1999; Slattery, Pollatsek, \& Rayner, 2007; but see Sears, Sharp, \& Lupker, 2006, for a partial replication).

Experiments 1, 2, and 4 used Spanish stimuli, whereas Experiment 3 used English stimuli. The fact that words in Romance languages like Spanish are primarily multisyllabic and highly regular in their stress-to-sound correspondences may well lead to the emergence of different lexical structures and different coding schemes (see Grainger \& Jacobs, 1998). Furthermore, because of the regular phoneme-to-grapheme rules of Spanish (and unlike English), the phonology of the AN or DN is very much the same as that of their corresponding neighbors (i.e., orthographic neighbors tend to be phonologic neighbors as well). Nonetheless, what we should note is that empirical evidence concerning "orthographic neighborhood" effects in Spanish tends to show the same pattern as in English (e.g., neighborhood density/frequency effects: Carreiras, Perea, \& Grainger, 1997; Perea \& Rosa, 2002; Perea, Rosa, \& Gómez, 2003; density constraint on form priming: Perea \& Rosa, 2000; transposed-letter effects: Perea \& Estévez, 2008; Perea, Rosa, \& Gómez, 2005; Perea \& Lupker, 2004).

\section{Experiment 1 (Deletion Neighbors)}

The basic question examined in Experiment 1 was: Are DNs automatically activated during word identification? If so, do words compete with their DNs? We tested this by investigating whether

\footnotetext{
${ }^{1}$ However, it should be noted that investigations of $N$ have tended to overlook the correlation between this variable and other variables that affect visual word identification, including age-of-acquisition and imageability. In collaboration with Jeff Bowers, the first author has accumulated a body of unpublished data suggesting that facilitatory effects of $N$ in the lexical decision task disappear when these confounding variables are properly controlled.
} 
high-frequency DNs interfere with classification of low-frequency targets in the lexical decision task. Low-frequency words containing high-frequency DNs were matched with control words that did not possess a DN (e.g., juzgar vs. vestir; juzgar has the higherfrequency DN neighbor jugar). Words were pairwise matched on the Spanish frequency norms, as well as on length, bigram frequency, and $N$. We employed the same manipulation for nonword trials: Nonwords that contain embedded deletion neighbors should be more difficult to reject than control nonwords with no deletion neighbors (i.e., if presentation of a letter string leads to the automatic activation of any DNs, it should take longer to reject a nonword that has a DN compared to a matched control nonword with no DNs). This would provide support for the automatic activation of deletion neighbors.

To test whether the DN interference effect depends on position of overlap, the position of the DN word was varied factorially across three levels: (a) initial overlap (e.g., clavel [clave]), (b) final overlap (e.g., clavar [lavar]), and (c) outer overlap (e.g., flecha [fecha]).

\section{Method}

Participants. Twenty undergraduate students from the University of Valencia participated. All were native Spanish-language speakers, and had normal or corrected-to-normal vision.

Stimuli and design. The experimental stimuli consisted of 240 items: 120 low-frequency words (mean frequency $=3.9$ per million in the Spanish database; see Davis \& Perea, 2005) and 120 nonwords. All stimuli contained between six and eight letters, and between two and four syllables. None of the words had any higher frequency substitution neighbors, any transposition neighbors, or any addition neighbors. Half of the word stimuli possessed DNs that were of higher frequency than the stimulus word (mean frequency $=38$ per million). The position of the DN word was varied factorially across three levels: (a) initial overlap (e.g., clavel), (b) final overlap (e.g., clavar), and (c) outer overlap (e.g., flecha). Each of the critical words was paired with a control word that did not possess a DN. Experimental and control words were matched with respect to length, number of syllables, $N$, bigram frequency and word frequency (see Table 1). The number of higher frequency syllabic neighbors (in the initial syllable; see Perea \& Carreiras, 1998) was also similar for the words with higherfrequency DNs and for the words with no DNs (125 and 141, respectively). With respect to the 120 nonwords, none of them had any substitution, transposition, or addition neighbors. Half of the nonword stimuli possessed DNs. The position of the DN word was also varied factorially across three levels: (a) initial overlap (e.g., minutor), (b) final overlap (e.g., gradical), and (c) outer overlap (e.g., olvindo). Each of the critical nonwords was paired with a control nonword that did not possess a DN. Experimental and control words were matched with respect to length, number of syllables, and bigram frequency. An additional set of 20 filler nonwords that had been created by substituting a letter from a word (and 20 filler words) were added to the experimental list to reduce the probability of a word having DNs.

Procedure. Participants were tested in a quiet room either individually or in groups of two or three. Presentation of the stimuli and recording of response times were controlled by PCcompatible computers. Participants were told that words and nonwords would be displayed on the monitor in front of them, and that they should press one of two buttons to indicate whether each stimulus was a word or a nonword, responding as rapidly as possible whereas maintaining a reasonable level of accuracy. Stimuli were presented in lower case and remained visible until the participant responded. Each participant received a total of 24 practice trials before the 280 experimental trials (including the 40 filler trials).

\section{Results and Discussion}

Incorrect responses (6.7\% for word targets and 5.6\% for nonword targets) and reaction times less than $250 \mathrm{~ms}$ or greater than $1,500 \mathrm{~ms}$ (less than 1\%) were excluded from the latency analysis. The mean latencies for correct responses and error rates are presented in Table 2. For word and nonwords targets, participant $(F 1)$ and item (F2) ANOVAs based on the participants' and items' response latencies and percentage error were conducted based on a 2 (presence/absence of higher-frequency DN) $\times 3$ (position of overlap of DN: initial, final, outer) design. All significant effects had $p$ values less than the .05 level.

Word targets. In the latency analysis, words with higherfrequency DNs were classified 20 ms more slowly than matched control words, $F 1(1,19)=8.88, M S E=1280.0, \eta^{2}=.32$; $F 2(1,57)=4.62, M S E=3348.8, \eta^{2}=.08$. This DN interference effect interacted with position of overlap in the analysis over participants, $F 1(2,38)=4.86, M S E=1843.9, \eta^{2}=.20$, but not in the analysis over items, $F 2<1$. This interaction reflected that there was a clear DN interference effect for the outer overlap condition $(48 \mathrm{~ms}, F 1(1,19)=14.66, M S E=$ $\left.1590.1, \eta^{2}=.44, F 2(1,19)=7.96, M S E=3305.9, \eta^{2}=.29\right)$,

Table 1

Characteristics of the Words in Experiment 1

\begin{tabular}{llccccc}
\hline DN condition & \multicolumn{1}{c}{ Examples } & Freq & $N$ & No. letters & No. syllables & MLBF \\
\hline Initial overlap & serial, anchoa & 3.7 & 0.1 & 6.7 & 2.7 & 2.26 \\
Matched control & turrón, acelga & 3.7 & 0.5 & 6.7 & 2.7 & 2.22 \\
Final overlap & calambre, frígida & 3.6 & 0.6 & 6.9 & 3.1 & 2.39 \\
Matched control & rumiante, enchufe & 3.6 & 0.4 & 6.9 & 3.1 & 2.30 \\
Outer overlap & camisón, juzgar & 4.4 & 0.4 & 6.9 & 2.9 & 2.43 \\
Matched control & esgrima, vestir & 4.4 & 0.2 & 6.9 & 2.9 & 2.38 \\
\hline
\end{tabular}

Note. $\quad N=$ average number of "substitution" neighbors; MLBF $=$ mean log bigram frequency; DN $=$ deletion neighbor. 
Table 2

Mean Lexical Decision Times (in Milliseconds) and Percentage of Errors (in Parentheses) for Word and Nonword Targets in Experiment 1

\begin{tabular}{lccr}
\hline & \multicolumn{3}{c}{ Position of overlap } \\
\cline { 2 - 4 } \multicolumn{1}{c}{ Variable } & Initial & Final & Outer \\
\hline Words & & & \\
$\quad$ Experimental & $770(10.3)$ & $760(5.5)$ & $809(9.8)$ \\
Control & $757(4.3)$ & $762(5.8)$ & $761(4.5)$ \\
DN interference & $13(10.0)$ & $-2(-0.3)$ & $48(5.3)$ \\
Nonwords & & & $875(7.5)$ \\
$\quad$ Experimental & $871(6.3)$ & $876(4.8)$ & $866(7.3)$ \\
Control & $840(3.3)$ & $-1(3.7)$ & $29(2.8)$ \\
DN interference & $31(3.0)$ & & \\
\hline
\end{tabular}

Note. $\quad \mathrm{DN}=$ deletion neighbor.

but not for the initial or final overlap conditions (13 and $-2 \mathrm{~ms}$, respectively, all $p \mathrm{~s}>.20$ ).

In the error analysis, words with higher-frequency DNs were classified less accurately than control words, $F 1(1,19)=9.12$, $M S E=44.0, \eta^{2}=.32, F 2(1,57)=7.77, M S E=51.6, \eta^{2}=.12$. Again, this DN interference effect interacted with position of overlap in the analysis over participants, $F 1(2,38)=4.90, M S E=$ $23.8, \eta^{2}=.21$, but not in the analysis over items, $F 2<1$. This interaction reflected that the DN interference effect occurred for the outer overlap condition $(5.3 \%, F 1(1,19)=16.54, M S E=16.6$, $\left.\eta^{2}=.47, F 2(1,19)=6.15, M S E=46.8, \eta^{2}=.24\right)$ and for the initial overlap condition $(6.0 \%, F 1(1,19)=7.48, M S E=48.2$, $\left.\eta^{2}=.28, F 2(1,19)=5.30, M S E=67.8, \eta^{2}=.22\right)$ but not for the final overlap condition $(-0.3 \%$, both $F \mathrm{~s}<1)$.

Nonword targets. In the latency analysis, nonwords with DNs were classified $20 \mathrm{~ms}$ more slowly than matched control nonwords, $F 1(1,19)=5.62, M S E=1933.3, \eta^{2}=.23, F 2(1,57)=5.69, M S E=$ $2476.9, \eta^{2}=.09$. This DN interference effect did not interact with position of overlap, both $p s>.15$, although by looking at Table 1, this effect is mainly driven by the outer overlap condition ( $29 \mathrm{~ms}$ ) and the initial overlap condition $(31 \mathrm{~ms})$ rather than by the final overlap condition $(-1 \mathrm{~ms})$. In the error analysis, nonwords with DNs were classified $3.2 \%$ less accurately than control nonwords, $F 1(1,19)=13.04, M S E=18.5$, $\eta^{2}=.41, F 2(1,57)=6.29, M S E=38.3, \eta^{2}=.10$.

In summary, we found evidence of DN interference for both words and nonwords. Position of overlap played an important role: Only words with DNs that share their outer letters (e.g., madrina, patoria) showed interference (over both response times and error rates) for both words and nonwords. Words with DNs that share their initial letters (e.g., armador, sonidol) showed interference over both response times and error rates for nonwords, and over error rates (but not response times) for words; and words with DNs that share their final letters (e.g., erizado, bescala) showed very little evidence of interference. This pattern is consistent with the (nonsignificant) trends observed in prior research (Bowers et al., 2005a; Davis \& Taft, 2005). We discuss these findings further in the General Discussion.

\section{Experiment 2 (Addition Neighbors)}

This experiment parallels Experiment 1 except that it manipulates the presence/absence of ANs instead of DNs. There are relatively few word pairs in which the higher-frequency member of the pair is an addition neighbor of the lower-frequency member, and thus our manipulation of position of overlap included only final and outer overlap conditions for word stimuli.

\section{Method}

Participants. Twenty-two undergraduate students from the University of Valencia participated. All were native Spanishlanguage speakers, and had normal or corrected-to-normal vision.

Stimuli and design. The experimental stimuli consisted of 190 items: 76 low-frequency words (mean frequency $=4.5$ per million in the Spanish database; see Davis \& Perea, 2005) and 114 nonwords of six to eight letters. The number of word stimuli was limited by the number of existing low-frequency words that possess addition neighbors. By contrast, there is considerable freedom in the construction of nonwords that possess addition neighbors, and thus we opted to include a greater number of nonwords than words to increase the power of the experimental manipulation. An additional set of 58 filler words and 20 filler nonwords (which were created by substituting a letter from a word) were added to the experimental list to reduce the probability of a word having DNs and to keep the proportion of words to 0.50 (i.e., 134 word trials and 134 nonword trials). None of the critical words or their controls had any higher-frequency SNs, any TNs, or any DNs. Half of the word stimuli possessed ANs that were of higher frequency than the stimulus word (mean frequency $=21$ per million). The position of the AN word was varied factorially across two levels: (a) final overlap (e.g., residir has the higher-frequency AN presidir), and (b) outer overlap (e.g., pasaje has the higher-frequency AN paisaje). Each of the critical words was paired with a control word that did not possess an AN. Experimental and control words were matched with respect to word frequency length, number of syllables, $N$, and bigram frequency (see Table 3 ). The number of higher-frequency syllabic neighbors (in the initial syllable) was also similar for the words with higher-frequency ANs and for the words with no ANs (132 and 143, respectively). With respect to the 114 nonwords, none of them had any SN, TN, or DNs. Half of the nonword stimuli possessed ANs. The position of the AN word was varied factorially across three levels: (a) initial overlap (e.g., azuca [azucar]), (b) final overlap (e.g., erfil [perfil]), and (c) outer overlap (e.g., sonisa [sonrisa]). Each of the critical nonwords was paired with a control nonword that did not possess an AN. Experimental and control words were matched with respect to length, number of syllables, and bigram frequency.

Procedure. The procedure of this experiment was identical to that in Experiment 1.

\section{Results and Discussion}

Incorrect responses (9.3\% for word targets and $9.3 \%$ for nonword targets) and reaction times less than $250 \mathrm{~ms}$ or greater than $1,500 \mathrm{~ms}$ (less than $1 \%$ ) were excluded from the latency analysis. ${ }^{2}$ The mean latencies for correct responses and error rates are pre-

\footnotetext{
${ }^{2}$ Eleven words were excluded from the analyses because of their high error rate, which exceeded a $40 \%$ error criterion: errado, impío, ducado, nuncio, estival, fiado, logia, eslavo, atisbar, injerto, orfeón. The overall pattern of mean response times does not change when we include these words in the analyses.
} 
Table 3

Characteristics of the Words in Experiment 2

\begin{tabular}{llccccc}
\hline DN condition & Examples & Freq & $N$ & No. letters & No. syllables & MLBF \\
\hline Final overlap & genero, presidir & 4.6 & 0.6 & 6.2 & 2.9 & 2.95 \\
Matched control & héroe, atisbar & 3.6 & 0.6 & 6.2 & 2.9 & 2.23 \\
Outer overlap & consejo, paisaje & 4.8 & 0.6 & 6.3 & 2.8 & 2.51 \\
Matched control & arroyo, butaca & 4.4 & 0.6 & 6.3 & 2.8 & 2.21 \\
\hline
\end{tabular}

Note. $\quad N=$ average number of "substitution" neighbors; MLBF = mean log bigram frequency; DN $=$ deletion neighbor.

sented in Table 4. For word targets, ANOVAs were conducted based on a 2 (presence/absence of ANs) $\times 2$ (position of overlap of DN: final, outer) design. (For nonword targets, position of overlap had three levels [initial, final, outer].)

Word targets. In the latency analysis, words with higher frequency ANs were classified $24 \mathrm{~ms}$ more slowly than matched control words, $F 1(1,21)=7.79, M S E=1540.5, \eta^{2}=.27$, $F 2(1,27)=3.09, M S E=3266.2, p=.09, \eta^{2}=.09$. Although this AN interference effect did not interact significantly with position of overlap $\left(F 1(1,21)=2.71, M S E=2613.5, p=.11, \eta^{2}=.11\right.$, $\left.F 2(1,27)=2.65, M S E=3266.2, p=.11, \eta^{2}=.08\right)$, most of the AN interference effect occurred in the outer overlap condition (42 $\mathrm{ms}, F 1(1,21)=7.79, M S E=1540.2, \eta^{2}=.54, F 2(1,15)=4.72$, $\left.M S E=4364.1, \eta^{2}=.22\right)$ rather than in the final overlap condition $(6 \mathrm{~ms}$, both $F \mathrm{~s}<1)$. The error analysis only showed an effect of position of overlap in the analysis by participants, $F 1(1,21)=$ 6.68, $M S E=75.1, \eta^{2}=.24, F 2<1$.

Nonword targets. In the latency analysis, nonwords with ANs were classified $16 \mathrm{~ms}$ more slowly than matched control words, $F 1(1,21)=4.07, M S E=2025.6, p=.057, \eta^{2}=.16, F 2(1,27)=$ $10.45, M S E=2336.4, \eta^{2}=.17$. More important, this AN interference effect interacted with position of overlap, $F 1(2,42)=$ 14.25, MSE $=1439.0, \eta^{2}=.40, F 2(2,54)=12.51, M S E=$ 2336.4, $\eta^{2}=.32$. This interaction reflected that the AN interference effect occurred for the outer overlap condition $(45 \mathrm{~ms}$, $F 1(1,21)=9.45, M S E=2392.8, \eta^{2}=.31, F 2(1,18)=21.27$, $\left.M S E=2746.0, \eta^{2}=.54\right)$ and for the initial overlap condition (37 $\mathrm{ms}, F 1(1,21)=10.20, M S E=1383.1, \eta^{2}=.33, F 2(1,18)=6.92$, $M S E=2423.3, \eta^{2}=.28$ ), whereas there was some AN facilitatory

Table 4

Mean Lexical Decision Times (in Milliseconds) and Percentage of Errors (in Parentheses) for Word and Nonword Targets in Experiment 2

\begin{tabular}{lccc}
\hline & \multicolumn{3}{c}{ Position of overlap } \\
\cline { 2 - 4 } \multicolumn{1}{c}{ Variable } & Initial & Final & Outer \\
\hline Words & & $749(16.2)$ & $761(10.2)$ \\
$\quad$ Experimental & & $743(12.9)$ & $719(9.3)$ \\
Control & & $6(3.3)$ & $42(0.9)$ \\
$\quad$ AN interference & & $755(3.1)$ & $834(29.4)$ \\
Nonwords & $811(12.7)$ & $788(3.1)$ & $789(5.0)$ \\
$\quad$ Experimental & $774(2.2)$ & $-33(0.0)$ & $45(24.4)$ \\
Control & $37(10.5)$ & & \\
AN interference & &
\end{tabular}

Note. $\quad \mathrm{AN}=$ addition neighbor. effect for the final overlap condition $(-33 \mathrm{~ms}, F 1(1,21)=11.11$, $M S E=1127.6, \eta^{2}=.35, F 2(1,18)=4.82, M S E=1839.9, \eta^{2}=$ $.21)$.

In the error analysis, nonwords with ANs were classified less accurately than control nonwords, $F 1(1,21)=41.43, M S E=$ $108.0, \eta^{2}=.66, F 2(1,54)=47.60, M S E=81.2, \eta^{2}=.47$. This AN interference effect interacted with position of overlap, $F 1(2,42)=24.81, M S E=66.4, \eta^{2}=.54, F 2(2,54)=17.52$, $M S E=81.2, \eta^{2}=.39$. This interaction reflected that the AN interference effect occurred for the outer overlap condition $\left(24.4 \%, F 1(1,21)=40.19, M S E=163.0, \eta^{2}=.66, F 2(1,18)=\right.$ $\left.36.18, M S E=156.3, \eta^{2}=.67\right)$ and for the initial overlap condition $\left(10.5 \%, F 1(1,21)=20.09, M S E=60.7, \eta^{2}=.49\right.$, $\left.F 2(1,18)=17.62, M S E=59.7, \eta^{2}=.50\right)$, whereas there were no signs of an AN effect for the final overlap condition ( $0.0 \%$, both $F$ s $<1)$.

In the present experiment, we found evidence of interference from ANs for both words and nonwords. For nonword targets, there was a robust $\mathrm{AN}$ interference effect over both response times and error rates (45 $\mathrm{ms}$ and $24.4 \%$ ): the very high percentage of errors in the outer overlap condition reflects the high degree of perceptual similarity between these AN nonwords and their corresponding base words (e.g., we obtained errors over $50 \%$ for nonwords such as for juvetud [juventud], econmía [economía], libetad [libertad], or pelíula [película]). initial overlap AN nonwords also showed clear interference effects over both response times and error rates (37 ms and $10.5 \%$; e.g., nonwords such as varieda [variedad] or superio [superior] with error rates over $30 \%$ ). Finally, final overlap AN nonwords showed the opposite trend (i.e., a facilitatory AN effect): response times were $33 \mathrm{~ms}$ faster than in the matched control condition; the cause of this facilitatory effect is not clear (see General Discussion).

With respect to the word stimuli, there was a significant effect of AN interference, which occurred mostly in the outer overlap condition (42 ms, $0.9 \%$ of errors), rather than in the final overlap condition (6 ms, $3.3 \%$ of errors).

\section{Experiment 3 (Addition Neighbors, English Stimuli)}

The experiments reported thus far demonstrate clear evidence of AN and DN interference effects, as well as showing that this effect interacts with position of overlap. However, these experiments were conducted using Spanish stimuli, and there is a question regarding whether the observed effects will generalize to other languages. In particular, Spanish differs from English in a couple of important respects. 
First, Spanish has a very regular syllable structure, as compared to a stress-based language like English. Spanish words tend to be composed of a set of common short syllables, and syllabic units may play a larger role for Spanish readers than for English readers (e.g., see Perea \& Carreiras, 1998, for evidence of syllabic effects in Spanish). AN/DN neighbors usually disrupt only one of the syllables of a word, leaving the remaining syllables intact (e.g., the AN/DN neighbors eslavo and esclavo would be syllabified as es.la.vo and es.cla.vo). Therefore, there is at least a possibility that the results obtained in Experiments 1 and 2 reflect syllable-based processes rather than the orthographic input coding of letters.

Another important respect in which Spanish differs from languages like English (and French) is the transparency of the mapping from orthography to phonology: in Spanish the correspondence between letters and phonemes is essentially one-toone. One consequence of this for AN/DN interference effects is that the addition or deletion of a letter will typically have less effect on the pronunciation of the resulting string than is the case for a language like English, in which the orthography to phonology mapping is more opaque. For example, this opacity gives rise to AN/DN pairs like though-tough, in which there is great orthographic overlap, but no phonologic overlap. It is therefore conceivable that the AN/DN interference effects observed in Spanish reflect phonologic rather than orthographic overlap, and that these effects may not be as strong in a language like English.

The argument that AN/DN interference effects reflect orthographic processes, rather than syllabic or phonologic processes, would receive much stronger support if a similar pattern were found in English. At present, the available evidence suggests that English does behave much like Spanish (see Lupker et al., 2008; Perea \& Lupker, 2004). Davis and Taft (2005) demonstrated inhibitory effects of higher frequency DNs on lexical decisions to word stimuli in an English-language experiment. Furthermore, there was a significant interaction of DN interference and position of overlap that showed a very similar quantitative pattern to that observed in Experiment 1, that is, strong interference for outer overlap DNs, moderate interference for initial overlap DNs, and no interference for final overlap DNs.

Therefore, we can be confident that the DN interference results observed in Experiment 1 are also observed in English. However, the effect of higher frequency ANs has yet to be investigated in an English-language lexical decision experiment. Our goal in Experiment 3 was to verify that the AN interference effects reported for Spanish stimuli in Experiment 2 would generalize to English stimuli. Our expectation was that we would observe a similar pattern of effects as in Experiment 2, i.e., that Spanish and English would exhibit similar AN interference effects.

\section{Method}

Participants. Forty-two undergraduate students from the University of Bristol participated. All were native English-language speakers, and had normal or corrected-to-normal vision.

Stimuli and design. We constructed nonword stimuli that possessed ANs by starting with a set of 42 high-frequency, six-letter words with no conventionally defined (substitution) neighbors (mean CELEX frequency $=112$ per million). For each of these words we created three DN neighbor nonwords, by deleting either an initial, medial, or final letter. For example, from the word salary, we constructed the three nonwords alary, salry, and salar. Each of the resulting nonwords was paired with a one-letter different orthographic control nonword that did not possess any addition neighbors (e.g., alart, silry, sular). The control nonwords were closely matched with the experimental nonwords with respect to $N(M=0.9)$ and mean log bigram frequency $(M=2.28)$; control nonwords were also closely matched with the experimental nonwords with respect to the number of items that possessed DNs (24 and 28, respectively), and the mean frequency of these DNs (78 and 72 per million, respectively). Three separate versions of the experiment were constructed so that the three nonwords associated with each six-letter base word were responded to by different participants (furthermore, each experimental nonword and its control nonword were responded to by different participants).

We also sought to examine AN interference effects for word stimuli, although a fully balanced factorial manipulation of the position of overlap was not feasible, given the restriction that we wanted all words to be five letters in length, to match the nonwords. We selected 44 word stimuli possessing ANs that were of higher frequency than the stimulus word (mean frequency $=88$ per million). Each of these critical words was paired with a control word that did not possess an AN. The position of the AN word varied, such that it overlapped with the outer letters of the target for 23 words (e.g., petty has the higher frequency AN pretty) and with the final letters of the target for 15 words (e.g., error has the higher frequency AN terror). A further six words possessed higher frequency ANs that overlapped with the initial letters of the target (e.g., rabbi has the higher-frequency AN rabbit). The small number of items in the latter condition reflects the difficulty of finding initial overlap AN pairs that are not morphologically related; although this small number of items is insufficient for a reliable inferential test, we thought it would be interesting to examine the direction of any numerical trends for these items. Experimental and control words were matched with respect to word frequency length, number of syllables, $N$, and bigram frequency (see Table 5); experimental and control words were also matched with respect to age of acquisition and image ability, based on the norms reported by Stadthagen-Gonzalez and Davis (2006).

An additional set of 18 filler words and 14 filler nonwords (created by substituting one letter of a word) were added to the experimental list to reduce the probability of a word having ANs and to keep the proportion of words to 0.50 . In total, there were 102 word trials and 102 nonword trials.

Procedure. The procedure of this experiment was identical to that in Experiments 1 and 2.

\section{Results and Discussion}

Incorrect responses (9.9\% for word targets and $8.7 \%$ for nonword targets) and reaction times less than $250 \mathrm{~ms}$ or greater than $1,500 \mathrm{~ms}$ (less than $1 \%$ ) were excluded from the latency analysis. Ten words that were incorrectly classified by more than a third of participants were excluded from the analyses (these items are marked in Appendix A). The exclusion of these items did not affect the balancing of conditions or the matching of experimental words to controls. Four of the excluded words were from the small exploratory sample of initial overlap items (and their controls), and hence their exclusion did not affect the two-level manipulation of 
Table 5

Characteristics of the Words in Experiment 3

\begin{tabular}{lllcccr}
\hline AN condition & Examples & Freq & $N$ & No. letters & No. syllables & MLBF \\
\hline Final overlap & narrow, terror & 20.5 & 2.5 & 5 & 1.50 & 2.69 \\
Matched control & blunt, essay & 19.1 & 2.1 & 5 & 1.33 & 2.78 \\
Outer overlap & pretty, thread & 10.3 & 3.3 & 5 & 1.48 & 2.71 \\
Matched control & lousy, blend & 10.0 & 2.8 & 5 & 1.48 & 2.66 \\
\hline
\end{tabular}

Note. $\quad N=$ average number of "substitution" neighbors; MLBF = mean log bigram frequency; $\mathrm{AN}=$ addition neighbor.

position of overlap for words. The mean latencies for correct responses and error rates are presented in Table 6. For word targets, ANOVAs were conducted based on a 2 (presence/absence of ANs) $\times 2$ (position of overlap of DN: final, outer) design. For nonword targets, position of overlap had three levels: initial, final, and outer.

Word targets. In the latency analysis, there was no overall AN interference effect, $F 1(1,41)=1.20, M S E=2152.63, \eta^{2}=.02$, $F 2(1,66)=1.29, M S E=1680.41, \eta^{2}=.02, p>.05$, but there was a significant interaction of this factor with position of overlap, $F 1(1,41)=23.17, M S E=788.30, \eta^{2}=.36, p<.001, F 2(1,66)=$ $4.75, M S E=1680.41, \eta^{2}=.07, p<.05$. This interaction reflected a large AN interference effect in the outer overlap condition, $F 1(1,41)=12.54, M S E=1377.69, \eta^{2}=.23, p<.01, F 2(1,38)=$ $5.42, M S E=1989.52, \eta^{2}=.13, p<.05$, compared to a nonsignificant difference (and a numerical trend in the opposite direction) in the final overlap condition, $F 1(1,41)=2.28, M S E=$ 1563.24.11, $\eta^{2}=.05, F 2<1, p>.05$. The small sample of initial AN overlap words showed no evidence of an interference effect relative to the matched controls (the means were $657 \mathrm{~ms}$ and 653 $\mathrm{ms}$, respectively).

The results of the error analysis paralleled the latency analysis. There was no overall AN interference effect, $F 1(1,41)=1.55$, $M S E=43.64, p>.05, F 2(1,66)=0.48, M S E=57.13, p>.05$, but the interaction of this factor with position of overlap was significant in the analysis over participants, $F 1(1,41)=11.38$, $M S E=45.00, \eta^{2}=.25$, and approached significance in the analysis over items, $F 2(1,66)=3.66, M S E=57.13, \eta^{2}=.11, p=$ .06. This interaction reflected an $\mathrm{AN}$ interference effect in the

Table 6

Mean Lexical Decision Times (in Milliseconds) and Percentage of Errors (in Parentheses) for Word and Nonword Targets in Experiment 3

\begin{tabular}{lccc}
\hline & \multicolumn{3}{c}{ Position of overlap } \\
\cline { 2 - 4 } \multicolumn{1}{c}{ Variable } & Initial & Final & Outer \\
\hline Words & & $612(7.0)$ & $655(12.4)$ \\
$\quad$ Experimental & & $623(9.2)$ & $622(7.6)$ \\
Control & & $-11(-2.2)$ & $33(4.8)$ \\
$\quad$ AN interference & & $667(9.1)$ & $715(19.3)$ \\
Nonwords & $662(7.8)$ & $654(5.6)$ & $654(3.8)$ \\
$\quad$ Experimental & $645(6.9)$ & $13(3.5)$ & $61(15.5)$ \\
Control & $17(0.9)$ & & \\
AN interference & &
\end{tabular}

Note. $\quad \mathrm{AN}=$ addition neighbor. outer overlap condition that was significant in the analysis over participants, $F 1(1,41)=9.53, M S E=49.97, \eta^{2}=.25$, and showed a nonsignificant trend in the analysis over items, $F 2(1,38)=3.14, M S E=72.26, \eta^{2}=.25, p=.09$, compared to a nonsignificant difference (and a numerical trend in the opposite direction) in the final overlap condition, $F 1(1,41)=2.68, M S E=$ $38.66, p>.05, F 2(1,28)=1.01, M S E=36.58, p>.05$. The small sample of initial AN overlap words showed no evidence of an interference effect relative to the matched controls (the means were $13.1 \%$ and $16.1 \%$, respectively).

Nonword targets. In the latency analysis, nonwords with ANs were classified $30 \mathrm{~ms}$ more slowly than matched control words, $F 1(1,41)=48.48, M S E=1811.89, \eta^{2}=.54, F 2(1,41)=38.10$, $M S E=1526.96, \eta^{2}=.54$. This AN interference effect interacted with position of overlap, $F 1(2,82)=9.71, M S E=2393.96, \eta^{2}=$ $.19, F 2(2,82)=5.38, M S E=2825.05, \eta^{2}=.19$. This interaction reflected that there was a large $\mathrm{AN}$ interference effect for the outer overlap condition $(61 \mathrm{~ms}, F 1(1,41)=38.17, M S E=3135.70$, $\left.\eta^{2}=.48, F 2(1,41)=25.71, M S E=3077.17, \eta^{2}=.39\right)$, but (following Bonferroni correction) nonsignificant trends toward interference in the initial overlap condition $(17 \mathrm{~ms}, F 1(1,41)=$ 5.01, MSE $=2056.12, \eta^{2}=.07, F 2(1,41)=2.42, M S E=$ $\left.2455.88, \eta^{2}=.06, p>.05\right)$, and final overlap condition (13 ms, $F 1(1,41)=3.08, M S E=1408.00, \eta^{2}=.07, F 2(1,41)=2.15$, $\left.M S E=1644.01, \eta^{2}=.05, p>.05\right)$.

In the error analysis, nonwords with ANs were classified $6.6 \%$ less accurately than matched control words, $F 1(1,41)=31.75$, $M S E=74.72, \eta^{2}=.44, F 2(1,41)=26.30, M S E=105.11, \eta^{2}=$ .39. This AN interference effect interacted with position of overlap, $F 1(2,82)=15.50, M S E=66.51, \eta^{2}=.27, F 2(2,82)=18.29$, $M S E=69.73, \eta^{2}=.31$. This interaction reflected that there was a large AN interference effect for the outer overlap condition $\left(15.5 \%, F 1(1,41)=40.64, M S E=100.26, \eta^{2}=.50, F 2(1,41)=\right.$ $31.26, M S E=161.12, \eta^{2}=.43$.), but no interference in the initial overlap condition $(0.8 \%, F 1$ and $F 2<1)$. In the final overlap condition, there was a moderate interference effect $(3.5 \%)$ that was marginally significant in the analysis over participants, $F 1(1,41)=$ $6.22, M S E=57.51, \eta^{2}=.13, p=.051$, and showed a nonsignificant trend in the analysis over items, $F 2(1,41)=4.68, M S E=$ 56.51, $\eta^{2}=.10, p=.108$ ).

Overall, the results of this experiment suggest that AN interference effects in English are very similar to those observed in Spanish. In both languages there are large, statistically significant interference effects of outer overlap ANs for both words and nonwords. These interference effects are seen on both reaction time and accuracy measures, and tend to be larger for nonword stimuli than for word stimuli. 
In contrast to the large interference effects observed for outer overlap ANs, final overlap ANs (e.g., error-terror) showed no sign of producing interference in the speed or accuracy of responses to words, replicating the absence of such an effect in the Spanish data. However, there was some indication of weak interference from final overlap ANs in the nonword data, and the magnitude of this interference is consistent with what observed for nonwords with final overlap DNs in the Spanish stimuli of Experiment 1. Thus, there may be a genuine effect of final overlap similarity between AN-DN pairs, but this effect is quite small, and clearly much weaker than the outer overlap similarity effect.

It is not possible to draw any strong conclusions regarding the effect of initial overlap ANs on the identification of words, because of the relative infrequency of occurrence of this form of overlap in cases where is no morphologic relationship. This prevented us from including an initial overlap condition in Experiment 2, and the small number of items of this type in Experiment 3 is insufficient to draw any conclusions. The infrequency with which initial overlap AN-DN pairs are found in languages like Spanish and English may in itself reflect the potential perceptual confusability of such pairs.

The modest interference effect for nonwords with initial overlap ANs (wisdo-wisdom) in Experiment 3 is broadly consistent with the results of Experiment 2, although a slightly larger interference effect was observed in the latter experiment. The effect in Experiment 3 was statistically significant in the analysis over participants, but not in the analysis over items. Closer inspection of the priming effects revealed a possible source of variability across items. Recall that the nonwords with initial overlap ANs were constructed by deleting the final letter of a six-letter word. There were 18 cases where this resulted in a nonword that ended with a consonant (e.g., theor, derived from the AN theory). For these cases, the mean latency was $33 \mathrm{~ms}$ slower than the matched control nonwords (e.g., thaor), $t 2(17)=2.11, p=.050$; the difference in mean accuracy of $1.7 \%$ did not approach significance. There were a further 24 nonwords in the initial overlap condition that ended with a vowel; in 21 of these cases the final letter was $a, i, o$, or $u$. There was no sign of an interference effect for these nonwords relative to their matched controls over either latency (635 $\mathrm{ms}$ vs. $643 \mathrm{~ms}$, respectively, $t 2(20)<1$ ) or accuracy $(5.4 \%$ vs. $3.8 \%$, $t 2(20)=1.55, p>.05)$. Given that the letters $a, i, o$, or $u$ are relatively uncommon endings in English words (approximately $3.4 \%$ of five-letter words end with these vowels, compared to the $15.4 \%$ that might be expected if final letters were uniformly distributed across the alphabet), it seems feasible that the final letter may have been used as an indicator of lexical status. Participants may have been biased to respond "No" to nonwords with unusual endings, and this bias may have masked any AN interference effect for these items. Thus, the 33-ms initial AN interference effect observed with consonant-final nonwords may be a more reliable measure of the magnitude of interference from initial overlap ANs. It is noteworthy that the magnitude of this effect was very similar to the 37-ms interference effect observed in Experiment 2 for Spanish nonwords with initial overlap ANs.

In summary, the results of the present experiment with English stimuli replicate those of the prior experiments with Spanish stimuli, and therefore diminish any possible concerns that the pattern of effects found in those experiments are specific to languages that have very regular syllabic structure and/or transparent mappings from orthography to phonology. In both languages there is a very clear interference effect for outer overlap ANs, and some evidence of interference for initial overlap ANs (in the case of nonword stimuli); for final overlap ANs the evidence of an interference effect is at best, quite weak. This pattern of results is also consistent with the DN interference results reported by Davis and Taft (2005).

\section{Experiment 4 (AN and DN in Normal Reading)}

Experiments 1 through 3 demonstrated that there is a reliable inhibitory effect produced by the presence of a higher-frequency addition/deletion neighbor in a lexical decision judgment task, at least for AN/DNs that involve outer overlap. Experiment 4 was designed to explore this effect of neighborhood frequency within the context of normal silent reading. A good way to test whether there is competition among lexical entries is by monitoring readers' eye movements as they encode words in context during reading for meaning (Perea \& Pollatsek, 1998; see also Acha \& Perea, 2008; Paterson, Liversedge, \& Davis, in press; Pollatsek et al., 1999; Slattery et al., 2007). The rationale for this approach is that the linguistic characteristics of words have an impact both on the duration of fixations and on which words are fixated (e.g., see Rayner, 1998, for review). If this experimental method was to show a neighborhood frequency effect with AN/DN word stimuli there would be clear evidence that these effects are not restricted to laboratory word identification tasks and are actually influencing normal reading. Furthermore, the use of eye tracking techniques allows us to shed light on the time course of the effects, as the series of eye movements across a sentence offers a sequential record of the processing of the text.

The most relevant studies that have recorded eye movements in reading have obtained an inhibitory effect of neighborhood frequency. Perea and Pollatsek (1998; Pollatsek et al., 1999; Slattery et al., 2007; see also Sears, Sharp, \& Lupker, 2006, for a partial replication) observed an inhibitory effect of neighborhood frequency using substitution neighbors. Likewise, Pollatsek et al. (1999) examined the effect of neighborhood size in a sentencereading task when the neighborhood frequency of the targets embedded in the sentence was controlled. They observed that words with many substitution neighbors produced inhibitory effects on gaze duration and were skipped more often than words with few substitution neighbors. Furthermore, Pollatsek et al. showed that this inhibitory effect was modulated by the number of higher-frequency substitution neighbors of the target. That is, increasing the number of higher-frequency substitution neighbors had an inhibitory effect on word identification. The presence of an inhibitory effect of neighborhood frequency can be accommodated within the framework of the E-Z reader model of Reichle, Pollatsek, Fisher, and Rayner (1998; see also Pollatsek, Reichle, and Rayner, 2006, for an updated version of the model).

Specifically, the E-Z reader model posits two stages of lexical access (named L1 and L2) that occur during the processing of a word in text. Complete lexical access is only accomplished when both stages are completed. One might loosely relate L1 with an early activation stage in an activation-verification framework (Paap, Newsome, McDonald, \& Schvaneveldt, 1982). The end of L1 is thought to be the point at which there is sufficient activation from all this lexical activity so that there is a high probability that 
L2 (i.e., complete lexical access) would be achieved before the eyes moved to the next word (e.g., see Williams, Perea, Pollatsek, \& Rayner, 2006). In the "verification" stage, which loosely is linked to L2, there is competition among the various lexical entries. This implies that word units that are highly activated (e.g., a high-frequency neighbor) may inhibit word recognition in this stage. The net result is that words with higher-frequency competitors may induce some late effects (i.e., more refixations, longer duration of the first fixation after leaving the target word and/or a larger number of regressions back to the target word), and hence an increased total time, compared with matched control words. Indeed, this is precisely the pattern found in previous research on the neighborhood frequency effect with substitution neighbors (Perea \& Pollatsek, 1998; Pollatsek et al., 1999; Slattery et al., 2007).

Thus, the issue under consideration here was whether there would be a similar effect of neighborhood frequency of addition and deletion neighbors. To examine this question, we constructed 84 sentence frames. Each frame produced two sentences, one containing a target word that had a higher-frequency addition/ deletion neighbor and the other containing a control word that had no higher frequency (addition/deletion) neighbors. The key question was whether words that had higher-frequency (addition/ deletion) neighbors were harder to read than the target word that had no higher-frequency neighbors. The position of the higherfrequency (addition/deletion) neighbor was always in an internal position; bear in mind that this way we maximize the chances to obtain the inhibitory effect from the higher-frequency competitors (see Experiments 1-3 for evidence in lexical decision).

\section{Method}

Participants. Eighteen students from the Universitat de València took part in the experiment. They received a small monetary compensation ( $3 €)$ for their contribution. All participants had normal vision and were native speakers of Spanish. They were all naïve to the purpose of the experiment.

Materials. The stimuli comprised 84 pairs of sentences (see Appendix A). The members of each sentence pair were identical except for the target word. In one set the sentence contained a target word that had a higher-frequency addition/deletion neighbor (experimental set), whereas in the other set the sentence contained a control word that had no addition/deletion neighbors. To construct the experimental set, we used 42 target words classified into two groups: 19 target words had a higher-frequency AN (eslavoesclavo), and the remaining 23 had a higher-frequency DN (sigilosiglo). Control words were matched, on a pairwise basis, to experimental words in length $(M=6.6$, range 4-8) and word frequency ( $M=4.5$ and 5.6 per one million words for experimental and control words, respectively, in the Spanish database, Davis $\&$ Perea, 2005). The mean frequency of the higher-frequency addition/deletion neighbor was 45 per million. In addition, experimental and control words were matched on the mean number of SNs (0.8 and 1.0, respectively, $p>.50$ ), mean log bigram frequency ( 2.4 and 2.5 , respectively, $p>.50$ ), and the number of higher-frequency syllabic neighbors (in the initial syllable) (122 and 131, respectively, $p>.50$ ). Experimental words had no more than one higher-frequency (addition/deletion) neighbor and, in all cases, the neighbor was formed via the deletion or addition of a central letter (position 3-5). Two sentences were made for each target word to minimize a potential effect of context, and also to make it possible to test the same words across two different sentences, that is, each word appeared for each participant but it was rotated across the two lists (see Appendix A). Each sentence was no more than 62 characters in length, occupying one line on the display screen. Target words were always around the middle of the sentence (fourth or fifth position).

Design. Two lists were created, each containing 84 sentences. Each list contained the 42 target words (18 with a higherfrequency $\mathrm{AN}$ and 23 with a higher-frequency $\mathrm{DN}$ ) and the 42 control words. The sentences were counterbalanced across the two lists, so that the same sentence that included the target word in list one, included the control word in list two and vice versa. This way each participant could read all words in each list. As we created a pair of sentences per target, all participants were presented with all of the target and control words, that is, they saw both the word with a higher-frequency neighbor and its corresponding control, although in different sentence frames. The order of the experimental sentences was randomized independently for each participant. To ensure that ease with which the target words fitted into the sentential context was relatively balanced, we conducted a rating study in which 10 other participants saw the 84 pairs of sentences and were asked to rate the relative naturalness of the two sentences. They could respond that the sentence with higherfrequency (addition/deletion) neighbors was more natural, that the sentence with the control word was more natural or that both were equally natural, giving ratings of $1,-1$, and 0 , respectively. The result of this test $(t=-0.39, S D=.48, p>.50)$ indicated that the items were balanced in terms of how well the words fit in the sentence.

Apparatus. The eye movements of the participants were recorded with an EyeLink II eye tracker manufactured by SR Research Ltd. (Canada). The sampling rate for the pupil size and location is of $500 \mathrm{~Hz}$. The average gaze position error is less than $0.5^{\circ}$, and access to eye position data is done only with 3-ms delay. Registration was binocular, although only data from the right eye were analyzed. The position of the participant with respect to the screen was controlled by a head-tracking camera that served for compensating possible head motion.

Procedure. The experiment was conducted in a well-lit soundproof room. Participants were sitting in a fixed chair that ensured a distance of $75 \mathrm{~cm}$ from the center of the screen. After the calibration and validation process, participants read four practice sentences for comprehension. Each trial started with the presentation of a fixation point that was left aligned (coinciding with the location of the first letter of each sentence). Participants had to gaze at that point, and the system automatically corrected calibration drifts. When the fixation point disappeared from the screen, the target sentence was displayed. Participants were instructed to read for normal comprehension and to press one button on a gamepad device as soon as they finished reading the sentence. To ensure that participants attended to and understood the meaning of the sentences, they were asked to answer comprehension questions about the sentence they had just read after $20 \%$ of the sentences. Participants had little difficulty answering the questions correctly.

Data analysis. There are several ways to calculate the amount of time spent on the target word. Some dependent variables measure the early "first-pass" processing on the fixating word and include the probability of skipping the target word, the first fixa- 
tion duration, and gaze duration. The probability of skipping the target word represents the number of times the reader goes to the next word without fixating on the target word. First fixation duration is the amount of time a reader spends on the initial fixation on the target word. Gaze duration represents the sum of fixation durations on a target word before the reader leaves that word. In addition, other dependent variables measure "later processes," once the reader leaves the target word on his or her first pass through the text (Perea \& Pollatsek, 1998; Pollatsek et al., 1999). Those measures include spillover (the duration of the first fixation after leaving the target word), the probability of making a regression back to the target word and the total time spent on the target word (i.e., the sum of all fixation durations on the target word including regressive fixations).

\section{Results and Discussion}

A few sentences were excluded from the analyses because of problems monitoring the eye movements (less than 1\%). All fixations shorter than $80 \mathrm{~ms}$ or longer than $800 \mathrm{~ms}$ were excluded from the analyses. Fixation analyses were performed over the target words. The reliability of the effects was assessed across both participants and items. The design included Type of neighbor (AN, DN), Neighbor frequency (words with higher-frequency addition/ deletion neighbors, words with no higher-frequency addition/ deletion neighbors), and List (list 1, list 2) as factors. List was included as a dummy variable to extract the variance because of the counterbalancing lists (Pollatsek \& Well, 1995). The data are presented in Table 7.

First-pass measures. First fixation duration and skipping rate measures did not reveal any significant effects (all $p$ s $>.10$ ). More important, the ANOVA showed a reliable effect of neighborhood frequency on gaze durations. The mean gaze duration on target words with higher-frequency neighbors was greater than on control words (359 vs. $328 \mathrm{~ms}$, respectively), $F 1(1,16)=5.79$, $M S E=3094, \eta^{2}=.27, F 2(1,40)=8.78, M S E=5324, \eta^{2}=.18$. The effect of type of neighbor was significant over participants, $F 1(1,16)=5.13, M S E=1959.52, \eta^{2}=.24, F 2(1,40)=0.35$,

Table 7

Eye Movement Measures for the Target Words as a Function of Neighborhood Frequency and Type of Neighbor

\begin{tabular}{ccccccc}
\hline & \multicolumn{2}{c}{$\begin{array}{c}\text { Addition } \\
\text { neighbors }\end{array}$} & & \multicolumn{2}{c}{$\begin{array}{c}\text { Deletion } \\
\text { neighbors }\end{array}$} \\
\cline { 2 - 3 } \cline { 6 - 7 } Measure of reading & Exp. & Cont. & & Exp. & Cont. \\
\cline { 2 - 3 } First fixation duration (ms) & 252 & 249 & & 253 & 244 \\
$\quad$ Neighborhood freq. effect & 3 & & & 9 & \\
Gaze duration (ms) & 341 & 323 & & 378 & 333 \\
$\quad$ Neighborhood freq. effect & 18 & & & 45 & \\
Probability of skipping (\%) & 13.5 & 12.9 & & 15.0 & 12.1 \\
$\quad$ Neighborhood freq. effect & 0.6 & & & 2.9 & \\
Spillover (ms) & 356 & 357 & & 343 & 347 \\
Neighborhood freq. effect & -1 & & & -4 & \\
Percentage of regressions back & 34.6 & 32.5 & & 27.9 & 23.0 \\
$\quad$ Neighborhood freq. effect & 2.1 & & & 4.8 & \\
Total time on target word (ms) & 512 & 482 & & 545 & 476 \\
$\quad$ Neighborhood freq. effect & 30 & & & 69 & \\
\hline
\end{tabular}

Note. Exp. = experiment; Cont. $=$ control; freq. $=$ frequency.
$M S E=5683, p=.56, \eta^{2}=.02$. Although the inhibitory effect of neighborhood frequency was (numerically) larger for words with DNs than for words with ANs, the interaction between the two factors did not approach significance $(F 1(1,16)=1.71, M S E=$ 1857.6, $p>.15, \eta^{2}=.10, F 2(1,40)=1.05, M S E=5324.4, p>$ $\left..15, \eta^{2}=.03\right)$.

Later measures. The ANOVAs on the spillover effects did not reveal any significant effects (all $p s>.20$ ), as indicated by Pollatsek et al (1999) this measure is often noisy because this fixation could be on the word after the target word or on the word after that. A second late measure of processing is the probability of regressing back to the target word. Although the readers regressed back to the target word $3.5 \%$ more often when the target word had higher-frequency neighbors, the ANOVA failed to show any significant effects (all $p \mathrm{~s}>.10$ ). Finally, a cumulative measure of target-word processing is the total time spent on target words: The ANOVA on total time on the target word showed a significant effect of neighborhood frequency $(50 \mathrm{~ms}), F 1(1,16)=8.86$, $M S E=5007.1, \eta^{2}=.36, F 2(1,40)=5.08, M S E=23201.1, \eta^{2}=$ .11. Interestingly, the interaction of neighborhood frequency and type of neighbor approached significance in the analysis over participants, $F I(1,16)=3.89, M S E=1810.9 . p=.06, \eta^{2}=.20$, $F 2(1,40)=1.70, p=.20$ : The neighborhood frequency effect was numerically larger for DNs than for ANs (69 vs. $30 \mathrm{~ms}$ ).

In summary, the present eye movement experiment indicates that having a higher-frequency addition or deletion neighbor has an inhibitory effect on silent normal reading, extending the pattern found by Perea and Pollatsek (1998; Pollatsek et al., 1999; Slattery et al., 2007) with SNs. This inhibition effect was robust on gaze durations (32 ms) and in the total time spent on the target word (50 $\mathrm{ms})$. As in previous work, readers regressed back to the target word $3.5 \%$ more often when the target word had higher-frequency neighbors, although the effect was not statistically reliable.

\section{General Discussion}

The results of the present lexical decision and reading experiments indicate that the conventional definition of an orthographic neighbor is too restricted: perceptually similar words can be formed not only by letter substitutions (Coltheart et al., 1977), transpositions (Andrews, 1996), and combinations thereof (Davis \& Bowers, 2004, 2006), but also by letter deletions and additions. These results have significant implications for our understanding of orthographic input coding and the mechanisms used to identify visually presented words, as well as important methodologic implications.

\section{Do Neighbors Facilitate or Inhibit Visual Word Identification?}

A critical issue raised by the present data concerns the question of whether neighbors facilitate or inhibit word identification. Grainger and colleagues (e.g., Grainger \& Jacobs, 1996; Grainger et al., 1989, 1992) have reported many experiments in which higher-frequency $\mathrm{SNs}$ give rise to inhibitory effects. As noted earlier, though, experiments using English stimuli have produced mixed results, with some experiments showing inhibitory effects of higher frequency SNs (Huntsman \& Lima, 1996; Perea \& Pollatsek, 1998; Sears, Campbell, \& Lupker, 2006) and others 
showing null or facilitatory effects (e.g., Forster \& Shen, 1996; Sears et al., 1995, 2006; Siakaluk et al., 2002). However, our results for DNs and ANs appear to be much clearer, with both types of similarity resulting in inhibitory effects in both Spanish and English (cf. Davis \& Taft, 2005; Perea, Acha, \& Fraga, 2008). This inhibitory effect of higher-frequency neighbors supports the prediction of competitive network models in which identification is achieved through competition among lexical representations in the similarity neighborhood of the input stimulus (for other recent evidence supporting this framework, see Acha \& Perea, 2008; Bowers, Davis, \& Hanley, 2005b; Davis \& Lupker, 2006; Johnson, 2007; Perry, Lupker, \& Davis, 2008).

The present experiments have consistently shown evidence of an inhibitory effect on word processing of higher-frequency addition and deletion neighbors. In Experiment 1, using a singlepresentation paradigm, lexical decision latencies were slower and less accurate for words (and nonwords) with deletion neighbors of higher frequency (e.g., jugar in juzgar), relative to control stimuli. ${ }^{3}$ In Experiment 2, using a single-presentation paradigm, lexical decision latencies were slower and less accurate for words with ANs of higher frequency (e.g., conejo, which has the AN consejo), relative to control stimuli. Experiment 3 replicated this result in an experiment using English stimuli (e.g., there was evidence of interference for words like petty, which has the AN pretty). Finally, Experiment 4 replicated the inhibitory effect of having higher-frequency addition/deletion neighbors in a normal reading situation. The eye movement results are consistent with previous studies of Perea and Pollatsek (1998) and Pollatsek et al. (1999) using SNs. ${ }^{4}$ One advantage of measures obtained during silent reading, of course, is that they avoid the potential "contamination" of decision processes that may affect the reaction times obtained in the lexical decision task. As stated in the Introduction, in the E-Z model of eye movements (Reichle et al., 1998; see also Pollatsek et al., 2006), the process of word recognition during normal silent reading can be divided into two stages. The first stage is based on activation processes, in which all the words that share letters with the target are activated. This process can be captured by first-pass measures in silent reading. However, lexical access is not completed until the correct word is discriminated. This is likely to occur at a second stage of word processing, which is characterized by inhibitory processes among the activated candidates until the correct one is selected. The fact that the inhibitory effect of neighborhood frequency is found in gaze durations rather than in first fixation durations (or in the probability of skipping the target words) seems to suggest that these inhibitory processes occur relatively late, possibly reflecting verification processes (see also Pollatsek et al., 1999, for evidence of competition effects in gaze durations with $\mathrm{SNs}$ ).

In summary, the results of the present experiments provide further support for the conclusion that orthographic neighbors (whether formed by letter substitutions or additions/deletions) exert an inhibitory influence on visual word identification, and that this inhibitory effect is probably greatest in the latter stages of the identification process.

\section{Implications for Orthographic-Input Coding Schemes}

The present results also have important implications for orthographic-input coding schemes. Our findings pose additional problems for the position-specific input coding schemes used in most current computational models of visual word recognition (e.g., the IA model, McClelland \& Rumelhart, 1981, and its successors, the multiple read-model, Grainger \& Jacobs, 1996, and the DRC model, Coltheart et al., 2001, as well as recent models in the parallel distributed processing framework, e.g., Harm \& Seidenberg, 2004, as well as the hybrid CDP + model, Perry et al., 2007). As noted in the Introduction, a position-specific input coding scheme based on absolute position can explain the interference effects for initial overlap ANs and DNs. However, such a scheme cannot explain the interference effects that we observed for outer overlap ANs and DNs. Likewise, the version of slotcoding proposed by Jacobs et al. (1998) can explain interference effects for outer overlap ANs and DNs, but does not explain the interference for initial overlap pairs, or why this interference should be greater than for final overlap pairs. Finally, vowelcentered slot-coding schemes have difficulty explaining why interference should be observed for initial- and outer overlap pairs, but not for final overlap pairs. In any case, the latter type of scheme is restricted to coding monosyllabic words, and is therefore unsuited to explaining the present results with polysyllabic stimuli.

Finding a coding scheme that can accommodate the present effects is an important problem that needs to be solved by computational models of visual word recognition. One step in this direction is the spatial coding scheme used in the SOLAR model (Davis, 1999, 2004). In this coding scheme, letter units are position independent and the relative activities across these letter units codes the relative order of the letters in a string. The spatial coding scheme readily accommodates the perceptual similarity of transposition neighbors (Andrews, 1996; Chambers, 1979; Davis \& Andrews, 2001; Perea \& Lupker, 2003, 2004; Perea \& Pérez, in press; Lupker, Perea, \& Davis, 2008), because the spatial codes for TN pairs are very similar, involving slightly different patterns of activity over exactly the same set of units. The model also accounts for the perceptual similarity of neighbors once-removed, as well as for the finding that these pairs are less similar than substitution neighbors (Davis \& Bowers, 2004, 2006).

\footnotetext{
${ }^{3}$ The picture was not quite as clear for nonwords: having an addition neighbor was strongly inhibitory (over both reaction times and error rates) in the case of outer overlap neighbors, but there was an indication of a facilitatory trend over reaction times in the case of final overlap neighbors. The latter result is inconsistent with our other findings and with the findings in English reported by Davis and Taft (2005), nor is it clear how a facilitatory effect on No decisions should be interpreted, and so we are inclined to treat this trend as statistical noise.

${ }^{4}$ A recent study of Sears et al. (2006) replicated the Perea and Pollatsek eye movement (Perea \& Pollatsek, 1998) experiment. However, in a second study, Sears et al. failed to obtain an inhibitory effect of neighborhood frequency with SNs. The reasons why they failed to obtain an effect of neighborhood frequency are not clear, although it may be related to the fact that higher-frequency neighbors of the Sears et al. target stimuli differed at the first or last letter position. Furthermore, some of the Sears et al. control items had a higher-frequency neighbor according to one or both of the CELEX and Francis and Kučera corpuses. Another recent study by Slattery et al. (2007) has observed an inhibitory neighborhood frequency effect in reading with English words. Such differences reinforce the difficulties of methodological designs that seek to match stimuli across extraneous variables (cf. Bowers et al., 2005b). Of course, the present experiments are not immune from this criticism.
} 
When spatial coding is used, ANs and DNs are also coded by similar patterns of activity across the same set of letter units. Some examples are shown in Figure 1. As can be seen, the spatial codes for the word spine and its deletion neighbors spin, pine, and sine are very similar: their common letters are coded by the same letter units, and the relative pattern across these letter units is either identical (in the case of spine-spin and spine-pine) or very similar (in the case of spine-sine). The way in which the match between two spatial codes is computed is based on the similarity of their respective spatial patterns, and is described in detail in Davis (2004).

In the basic version of this computation, equivalent match values are computed for initial overlap and final overlap pairs, and slightly smaller match values are computed for outer overlap pairs, because of the slight disruption of letter contiguity that occurs when an internal letter is added or deleted. Consequently, the basic spatial coding model has difficulty explaining the position of overlap effects that were observed in the present experiments, particularly the apparent absence of interference effects for final overlap AN/DNs. This issue is discussed in more detail in the next section.

An alternative approach to input coding is offered by openbigram coding (e.g., Grainger \& van Heuven, 2003; Grainger et

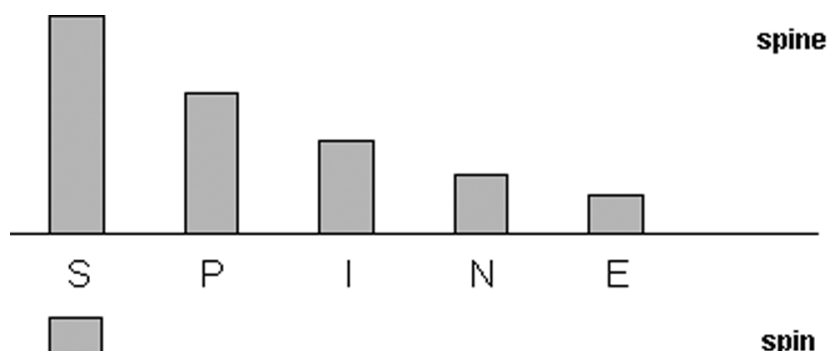

spin
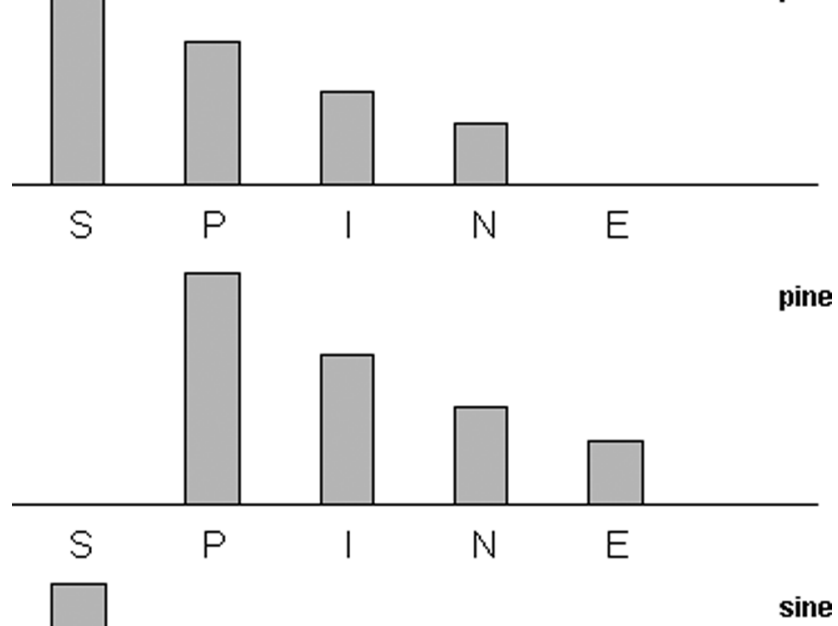

sine

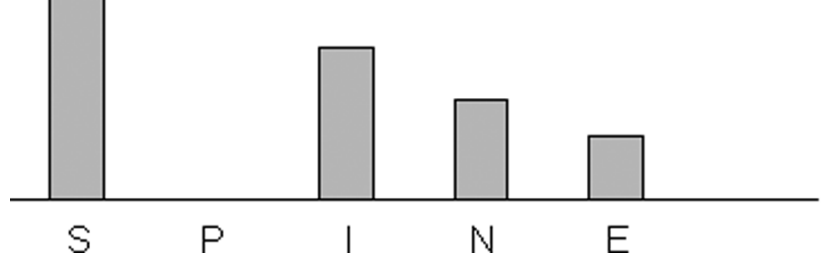

Figure 1. Spatial codes for the word spine and its deletion neighbors spin, pine, and sine. Note that the common letters in these words are coded by the same letter units, and that the relative pattern across these letter units is identical (for spine-spin and spine-pine) or very similar (for spine-sine). al., 2006; Schoonbaert \& Grainger, 2004; Whitney \& Berndt, 1999; Whitney, 2001, 2004). In this type of coding scheme, a letter string is coded in terms of all of the ordered letter pairs that it contains. (There is usually a limit imposed on the number of intervening letters in an open-bigram; e.g., Grainger and van Heuven, 2003, suggested that there should be a limit of two intervening letters.) For example, the word clam would be coded by the set $\{c l, c a, c m, l a, l m, a m\}$, and is therefore relatively similar to the TN word calm, which is coded by the set $\{c a, c l, c m, a l, a m, l m\}$ (i.e., the two words share five out of six open-bigrams). Thus, open-bigram coding is able to explain the perceptual similarity of TNs. This type of coding can also explain the perceptual similarity of AN/DN pairs. For example, in the constrained open-bigram coding scheme described by Grainger and van Heuven (2003), the word border would be coded by the set $\{b o, b r, b d, o r, o d, o e, r d, r e, r r, d e, d r, e r\}$, which shares nine of its 12 open-bigrams with its final overlap DN order. Likewise, orders and order share nine out 12 openbigrams. However, the perceptual similarity of outer overlap AN/DN pairs is not as great in this scheme. For example, window shares only 7 of its 12 open-bigrams with it outer overlap DN widow. Consequently, like the original spatial coding model, some modification to this scheme is required to explain the present findings, in which outer overlap pairs tended to result in much stronger effects than final overlap pairs.

In the Overlap model (Gómez et al., in press), the assumption is made that letter representations extend beyond their specific letter position into neighboring letter positions. The encoding activation of a given letter at a specific letter position is represented as a normal distribution with the peak of the curve falling at the correct letter position (see also Ratcliff, 1981). The distribution of activation extends into other letter positions. Because this encoding of letter position is noisy, the letters $d$ and $g$ in the TL nonword jugde are encoded at their respective letter position as well as at adjacent locations, although to a lesser degree. This model can thus predict the finding that TL nonwords (e.g., jugde) are more similar to their base words than substitution-letter nonwords (junpe). However, what is the perceptual similarity between words like window and widow? The overlap model has been extended to words of different length by assuming that letter position in a string of letters of similar length is coded relative to the start and end of the string (see Henson, 1998, for a similar start-end procedure). Further simulation work is needed to examine whether this model can capture the differential effects of ANs and DNs depending on the position of overlap.

\section{Why Are AN and DN Interference Effects Not Observed for Final Overlap Neighbors?}

A noteworthy aspect of the present results was the finding that AN/DN interference effects are either very weak, or not observed at all for final overlap neighbors (but are quite large for outer overlap neighbors, and are often observed for initial overlap neighbors). This finding is consistent with the results obtained by Bowers et al. (2005a) and Davis and Taft (2005), and adds to other evidence that the exterior letters of a word play a particularly important role in visual word identification (e.g., Jordan, 1990; Perea, 1998; Rayner, White, Johnson, \& Liversedge, 2006). It seems likely that this is related to the fact that the position of the 
exterior letters is coded in a more stable fashion than the positions of interior letters (e.g., Estes, Allmeyer, \& Reder, 1976; Mewhort, Marchetti, \& Campbell, 1981). However, although both of the exterior letters of a word may enjoy some priority over interior letters, our results suggest that it is the initial letter that is especially important.

The position-specific basis of the overlap model provides a natural explanation for why initial overlap DN-AN pairs like drive and drivel should be more similar than final overlap pairs like river and driver. However, it is less clear how the model can explain the even greater similarity of outer overlap pairs like drive and derive, in which only the initial letter occupies the same position in the two words. Explaining this pattern will be a challenge for future versions of the overlap model to tackle. One approach might be to attempt to merge the assumptions of the overlap model with the type of slot-coding scheme proposed by Jacobs et al. (1998), in which letter position is coded relative to the outer letters.

A different approach to explaining the absence of AN and DN interference effects for final overlap neighbors is to assume that the initial letter plays a more important role in the matching process than subsequent letters. Davis (2004) has described an end-letter marking extension of the basic spatial coding scheme in which the model is less flexible with respect to the matching of letters that are expected to be in the initial or final positions of a word. A related idea has been proposed by Whitney (2004), who introduced end-bigrams in the SERIOL approach. These bigrams code the first and last letters (e.g., window and widow would share the end-bigrams _w and w_). It would be possible to assign greater weight to the end bigram representing the initial letter, so that final overlap AN-DNs would be less similar than AN-DNs that shared their initial letter. However, it is not clear that this would be sufficient to explain the complete absence of interference effects for words with final overlap AN-DNs. Furthermore, a potential disadvantage of this account is that it introduces a degree of position-dependence, thereby, for example, making it more difficult to explain the identification of familiar words in novel compounds. Clearly, further empirical work is required to evaluate different theoretical mechanisms for capturing the importance of exterior letters in lexical matching (cf. Davis, 2008; Whitney, in press).

An alternative explanation for the importance of the initial letter is that it is related to phonologic factors. According to such an account, the absence of neighbor frequency effects for final overlap AN/DNs is outside the scope of orthographic input coding models; some preliminary evidence for such an account has recently been observed in the first author's laboratory. It may be that the stimulus driver does produce a good match with the word river, but that it also leads to the rapid activation of the phoneme /d/, and that this phonological activation then strictly constrains the set of activated lexical candidates, thereby suppressing the activation of final overlap AN/DNs.

\section{Are AN/DN Interference Effects Purely Orthographic, or Partly Phonologic?}

A further issue concerns whether the interference effects that we report are specifically orthographic or could be partly phonologic. Such questions are difficult to resolve definitively for alphabetic languages. We do not rule out the possibility that there is a phonological contribution to the effects we report (and we would argue that such a contribution would not undermine the theoretical interest of these effects). Indeed, recent experiments reported by Bowers et al. (in press) demonstrate DN interference effects in the domain of auditory word recognition (where a DN is in this case defined as a word that differs from another by the deletion of a single phoneme). These experiments were based on the well-established category interference effect in picture-word naming (e.g., naming a picture of a bus is delayed by simultaneous presentation of the auditory distractor "car," and this interference effect is greater than that produced by a distractor from a different semantic category). Bowers et al. (in press) found that this interference effect was also observed when the auditory distractor was a superset of an associated word, e.g., "scar." Indeed, the interference effects from supersets like "scar" were as large as from the unembedded word (i.e., "car"). This finding implies that deletion neighbors are automatically activated during auditory word recognition, which presumably depends on phonologic codes, and is therefore relevant to the question of whether the interference effects reported in the present article extend to phonologic neighborhoods. However, Bowers et al. (in press) obtained equivalent interference effects when subsets were embedded at the beginning or end of the superset (e.g., "key"-"keen" vs. "car""scar"). In this respect, the phonologic interference effects appear to be rather different from those reported here.

There are a couple of other considerations that can at least be taken as support for the claim that the effects reported here are not primarily phonologic. The first is based on the fact that we observed such similar patterns of interference effects in Spanish (with its "shallow" orthography) and English (with its "deep" orthography). If the interference effects were largely phonologic, then one might expect that interference effects would be larger in Spanish than in English. Secondly, Bowers et al. (2005a) examined whether the interference effects produced by higher-frequency subset words in a semantic categorization task were affected by the phonological similarity of the word and its subset. They found that interference effects were of the same magnitude for cases in which the phonology was similar (e.g., hat-hatch) and cases where it was relatively different (e.g., ear-earn).

In summary, we would argue that AN/DN interference effects are relevant for both orthographic and phonologic neighborhoods, and that there may therefore be some phonologic contribution to the effects reported here, but that the principal locus of these effects is likely to be orthographic.

\section{Length-Sensitivity in Visual Word Identification}

A further implication of the present results for the mechanisms used to identify visually presented words relates to the potential role of length-sensitive mechanisms. If ANs and DNs are coded by similar orthographic input codes, such that, for example, presentation of the word window automatically activates its DN widow, the question that arises is how the identification system (usually) chooses the correct candidate, rather than its neighbor. Given that an AN-like window contains all of the letters of its DN (widow), it is not immediately apparent that the correct candidate will produce a better perceptual match than its competitor. This is an important problem for computational models of visual word identification. 
One possible solution to this problem is to assume the existence of some sort of length-sensitive identification mechanism. For example, Smith et al. (1991) proposed the existence of "length" units that restrict the potential candidate set to words containing exactly the same number of letters as the current input stimulus. The interference effects obtained here, together with the results of other recent studies (Bowers et al., 2005a; Davis \& Taft, 2005; Schoonbaert \& Grainger, 2004; Van Assche \& Grainger, 2006), would appear to rule out the strictest form of length sensitivity. Nevertheless, this does not rule out the possibility of a more flexible length-sensitive mechanism, in which some "margin of error" is allowed, or in which candidates are weighted continuously according to the similarity between their lengths and the length of the current stimulus. Further examination of embedded words may help to assess such a possibility. For example, the perceptual similarity of pairs that differ with respect to the addition/deletion of two letters could be examined (e.g., palace-parlance; render-reindeer).

A second possible solution to the problem of distinguishing ANs and DNs is to rely on letter-word inhibition. That is, detection of the letter $N$ in window, which distinguishes it from its DN, could result in an inhibitory signal to the lexical representation WIDOW, which would help the system to identify the correct candidate. This type of bottom-up inhibition is a feature of the original interactive-activation model and related models (Coltheart et al., 2001; Grainger \& Jacobs, 1996; McClelland \& Rumelhart, 1981). Davis (1999), on the other hand, discussed several reasons for avoiding this sort of inhibition. The present data may be relevant for resolving this issue. If letter units send inhibition to incompatible word representations, it follows that addition neighbors should be more strongly activated than deletion neighbors (e.g., "widow" should activate WINDOW more strongly than "window" activates WIDOW). It follows that interference effects should be greater for words that have addition neighbors than for those that have deletion neighbors. However, the results of the present experiments provide no support for this prediction. For instance, in normal silent reading (Experiment 4), target words with higher frequency addition neighbors showed smaller interference effects than those with higher-frequency deletion neighbors.

A third possibility is that length sensitivity is achieved through masking field principles (Cohen \& Grossberg, 1984), as in the SOLAR model (Davis, 1999). Briefly, these specify that representations of longer words enjoy a competitive advantage over representations of shorter words but, critically, require greater inputs to become activated. For example, when the stimulus is window, the lexical representations for both WIDOW and WINDOW will be activated, but the latter will ultimately suppress the activity of its DN competitor WIDOW. However, when the stimulus is widow, the lexical representation for WINDOW does not receive its full input and hence will not become strongly activated. Thus, if there is a difference in the magnitude of AN and DN interference effects, it should be in the direction of greater interference from DNs than from ANs. This prediction agrees with the results of Experiment 4. On the other hand, Experiments 1 and 2 showed roughly equivalent (outer overlap) interference effects for ANs and DNs. Although it could be argued that the difference reflects the possibility that the eye-tracking experiment provides a more sensitive test than the lexical decision experiments, it would probably be wise to reserve judgment until further evidence is available. Nevertheless, the present results are at least broadly consistent with an account of AN/DN discrimination that relies on masking field principles.
Methodologic Implications

The methodologic implications of this work are straightforward. It is presently considered best practice to match stimuli in psycholinguistic experiments with respect to $N$. The basis for this practice is that responses to a word may be affected by its similarity to other words, and therefore the number of words to which it is similar should be controlled, so as to avoid confounds between this factor and the experimental factors of interest. The present findings confirm that similarity to other words influences responses both in the most popular laboratory word identification task (lexical decision) and in normal silent reading. It also shows, though, that it is insufficient to count the number of words that can be formed by substituting a single letter. Rather, stimuli should also be controlled with respect to the presence or number of addition and deletion neighbors. Ultimately, the development of a revised $N$ metric appears to be worth pursuing (see Dehaene, Cohen, Sigman, \& Vinckier, 2005, for a similar view). The optimal metric will probably be one which weighs neighbors according to their type (e.g., substitution, transposition, deletion, addition), position of overlap (initial, final, or outer), and frequency of occurrence. 5

In summary, the present experiments have shown that addition and deletion neighbors form part of a word's orthographic neighborhood. We have shown this pattern in the most popular visual word recognition task (lexical decision) and in normal silent reading, while the participant's eye movements were monitored. Furthermore, we have shown that the influence of these neighbors is (to some degree) qualified by the position of overlap. These findings have important methodological implications, as well as imposing constraints on the input coding schemes that are currently being developed in the field of visual word recognition.

\footnotetext{
${ }^{5}$ There are computer programs available to determine the number of substitution neighbors, transposition neighbors, addition neighbors, and deletion neighbors for sets of English words (N-Watch: Davis, 2005) or Spanish words (B-Pal: Davis \& Perea, 2005).
}

\section{References}

Acha, J., \& Perea, M. (2008). The effect of neighborhood frequency in reading: Evidence with transposed-letter neighbors. Cognition, 108, 290300 .

Andrews, S. (1996). Lexical retrieval and selection processes: Effects of transposed-letter confusability. Journal of Memory and Language, 35, 775800 .

Andrews, S. (1997). The effect of orthographic similarity on lexical retrieval: Resolving neighborhood conflicts. Psychonomic Bulletin and Review, 4, 439-461.

Bowers, J. S., Davis, C. J., \& Hanley, D. A. (2005a). Automatic semantic activation of embedded words: Is there a 'hat' in 'that'? Journal of Memory and Language, 52, 131-143.

Bowers, J. S., Davis, C. J., \& Hanley, D. A. (2005b). Interfering neighbours: The impact of novel word learning on the identification of visually similar words. Cognition, 97, 45-54.

Bowers, J. S., Davis, C. J., Mattys, S., Damian, M. F., \& Hanley, D. A. (in press). The activation of embedded words in spoken word perception is widespread. Journal of Experimental Psychology: Human Perception and Performance.

Carreiras, M., Perea, M., \& Grainger, J. (1997). Effects of orthographic neighborhood in visual word recognition: Cross-task comparisons. Journal 
of Experimental Psychology: Learning, Memory, and Cognition, 23, 857871.

Chambers, S. M. (1979). Letter and order information in lexical access. Journal of Verbal Learning and Verbal Behavior, 18, 225-241.

Cohen, M., \& Grossberg, S. (1984). Neural dynamics of brightness perception: Features, boundaries, diffusion, and resonance. Perception and Psychophysics, 36, 428-456.

Coltheart, M., Davelaar, E., Jonasson, J. T., \& Besner, D. (1977). Access to the internal lexicon. In S. Dornic (Ed.), Attention and performance VI (pp. 535-555). New York: Academic Press.

Coltheart, M., Rastle, K., Perry, C., Ziegler, J., \& Langdon, R. (2001). DRC: A Dual-Route Cascaded model of visual word recognition and reading aloud. Psychological Review, 108, 204-256.

Davis, C. J. (1999). The Self-Organising Lexical Acquisition and Recognition (SOLAR) model of visual word recognition. Unpublished doctoral dissertation. Available in electronic form at www.maccs.mq.edu.au/ $\sim$ colin

Davis, C. J. (2004). The SOLAR (Self-Organising Lexical Acquisition \& Recognition) model of visual word identification, Part I: Orthographic input coding and lexical matching. Manuscript submitted for publication.

Davis, C. J. (2005). N-Watch: A program for deriving neighborhood size and other psycholinguistic statistics. Behavior Research Methods, 37, 65-70.

Davis, C. J. (2008). SOLAR versus SERIOL: A response to Whitney (2008). Manuscript submitted for publication.

Davis, C. J., \& Andrews, S. (2001). Inhibitory effects of transposed-letter similarity for words and non-words of different lengths. Australian Journal of Psychology, 53, 50.

Davis, C. J., \& Bowers, J. S. (2004). What do letter migration errors reveal about letter position coding in visual word recognition? Journal of Experimental Psychology: Human Perception and Performance, 30, 923-941.

Davis, C. J., \& Bowers, J. S. (2006). Contrasting five theories of letter position coding. Journal of Experimental Psychology: Human Perception and Performance, 32, 535-557.

Davis, C. J., \& Lupker, S. J. (2006). Masked inhibitory priming in English: Evidence for lexical inhibition. Journal of Experimental Psychology: Human Perception and Performance, 32, 668-687.

Davis, C. J., \& Perea, M. (2005). BuscaPalabras: A program for deriving orthographic and phonological neighborhood statistics and other psycholinguistic indices in Spanish. Behavior Research Methods, 37, 665-671.

Davis, C. J., \& Taft, M. (2005). More words in the neighborhood: Interference in lexical decision due to deletion neighbors. Psychonomic Bulletin and Review, 12, 904-910.

Dehaene, S., Cohen, L., Sigman, M., \& Vinckier, F. (2005). The neural code for written words: A proposal. Trends in Cognitive Sciences, 9, 335-341.

de Moor, W., \& Brysbaert, M. (2000). Neighborhood-frequency effects when primes and targets are of different lengths. Psychological Research, 63, 159-162.

Estes, W. K., Allmeyer, D. H., \& Reder, S. M. (1976). Serial position functions for letter identification at brief and extended exposure durations. Perception and Psychophysics, 19, 1-15.

Forster, K. I., Davis, C., Schoknecht, C., \& Carter, R. (1987). Masked priming with graphemically related forms: Repetition or partial activation? Quarterly Journal of Experimental Psychology: Human Experimental Psychology, 39A, 211-251.

Forster, K. I., \& Shen, D. (1996). No enemies in the neighborhood: Absence of inhibitory neighborhood effects in lexical decision and semantic categorization. Journal of Experimental Psychology: Learning, Memory, and Cognition, 22, 696-713.

Gómez, P., Ratcliff, R., \& Perea, M. (2008). The overlap model: A model of letter position coding. Psychological Review, 115, 577-601.

Goldinger, S. D., Luce, P. A., \& Pisoni, D. B. (1989). Priming lexical neighbors of spoken words: Effects of competition and inhibition. Journal of Memory and Language, 28, 501-518.

Grainger, J. (2008). Cracking the orthographic code: An introduction. Language and Cognitive Processes, 23, 1-35.

Grainger, J., Granier, J. P., Farioli, F., Van Assche, E., \& van Heuven, W. (2006). Letter position information and printed word perception: The relative-position priming constraint. Journal of Experimental Psychology: Human Perception and Performance, 32, 865-884.

Grainger, J., \& Jacobs, A. M. (1996). Orthographic processing in visual word recognition: A multiple read-out model. Psychological Review, $103,518-565$.

Grainger, J., \& Jacobs, A. M. (1998). On localist connectionism and psychological science. In J. Grainger \& A. M. Jacobs (Eds.), Localist connectionist approaches to human cognition (pp. 1-38). Mahwah, NJ: Erlbaum.

Grainger, J., O'Regan, J. K., Jacobs, A. M., \& Segui, J. (1992). Neighborhood frequency effects and letter visibility in visual word recognition. Perception and Psychophysics, 51, 49-56.

Grainger, J., O’Regan, J. K., Jacobs, A. M., \& Segui, J. (1989). On the role of competing word units in visual word recognition: The neighborhood frequency effect. Perception and Psychophysics, 45, 189-195.

Grainger, J., \& van Heuven, W. J. B. (2003). Modeling letter position coding in printed word perception. In P. Bonin (Ed.), The mental lexicon (pp. 1-23). New York: Nova Science.

Harm, M. W., \& Seidenberg, M. S. (1999). Phonology, reading acquisition, and dyslexia: Insights from connectionist models. Psychological Review, 106, 491-528.

Henson, R. N. A. (1998). Short-term memory for serial order: The start-end model. Cognitive Psychology, 36, 73-137.

Huntsman, L. A., \& Lima, S. D. (1996). Orthographic neighborhood structure and lexical access. Journal of Psycholinguistic Research, 25, 417-429.

Jacobs, A. M., Rey, A., Ziegler, J. C., \& Grainger, J. (1998). MROM-p: An interactive activation, multiple read-out model of orthographic and phonological processes in visual word recognition. In J. Grainger \& A. M. Jacobs (Eds.), Localist connectionist approaches to human cognition (pp. 147-188). Mahwah: Erlbaum.

Johnson, R. L. (2007, November). The quiet clam is quite calm: Transposed-letter neighborhood effects in reading. Poster presented at the 48th Annual Meeting of the Psychonomic Society, Long Beach, CA.

Johnson, R. L., Perea, M., \& Rayner, K. (2007). Transposed-letter effects in reading: Evidence from eye movements and parafoveal preview. Journal of Experimental Psychology: Human Perception and Performance, 33, 209-229.

Jordan, T. R. (1990). Presenting words without interior letters: Superiority over single letters and influence of postmask boundaries. Journal of Experimental Psychology: Human Perception and Performance, 16, 893-909.

Landauer, T., \& Streeter, L. A. (1973). Structural differences between common and rare words: Failure of equivalence assumptions for theories of word recognition. Journal of Verbal Learning and Verbal Behavior, 12, 119-131.

Lupker, S. J., Perea, M., \& Davis, C. J. (2008). Transposed letter priming effects: Consonants, vowels and letter frequency. Language and Cognitive Processes, 23, 93-116.

McClelland, J. L., \& Rumelhart, D. E. (1981). An interactive activation model of context effects in letter perception: Part I. An account of basic findings. Psychological Review, 88, 375-407.

Mewhort, D. J. K., Campbell, A. J., Marchetti, F. M., \& Campbell, J. I. D. (1981). Identification, localization, and "iconic memory": An evaluation of the bar-probe task. Memory and Cognition, 9, 50-67.

Morton, J. (1970). A functional model for memory. In D. A. Norman (Ed.), Models of human memory (pp. 203-254). New York: Academic Press. Paap, K. R., Newsome, S. L., McDonald, J. E., \& Schvaneveldt, R. W. 
(1982). An activation-verification model for letter and word recognition: The word- superiority effect. Psychological Review, 89, 573-594.

Paterson, K. B., Liversedge, S. P., \& Davis, C. J. (in press). Inhibitory neighbor priming effects in eye movements during reading. Psychonomic Bulletin and Review.

Perea, M. (1998). Orthographic neighbours are not all equal: Evidence using an identification technique. Language and Cognitive Processes, 13, 77-90.

Perea, M., Acha, J., \& Fraga, I. (2008). Lexical competition is enhanced in the left hemisphere: Evidence from different types of orthographic neighbors. Brain and Language, 105, 199-210.

Perea, M., \& Carreiras, M. (1998). Effects of syllable frequency and neighborhood syllable frequency in visual word recognition. Journal of Experimental Psychology: Human Perception and Performance, 24, $1-11$.

Perea, M., \& Carreiras, M. (2006a). Do transposed-letter similarity effects occur at a prelexical phonological level? Quarterly Journal of Experimental Psychology, 59, 1600-1613.

Perea, M., \& Carreiras, M. (2006b). Do transposed-letter effects occur across lexeme boundaries? Psychonomic Bulletin and Review, 13, 418 422.

Perea, M., \& Carreiras, M. (2006c). Do transposed-letter similarity effects occur at a syllable level? Experimental Psychology, 53, 308-315.

Perea, M., \& Duñabeitia, J. A., \& Carreiras, M. (2008). Transposed-letter priming effects for close versus distant transpositions. Experimental Psychology, 55, 397-406.

Perea, M., \& Estévez, A. (2008). Transposed-letter similarity effects in naming pseudowords: Evidence from children and adults. European Journal of Cognitive Psychology, 20, 33-46.

Perea, M., \& Lupker, S. J. (2003). Transposed-letter confusability effects in masked form priming. In S. Kinoshita \& S. J. Lupker (Eds.), Masked priming: State of the art (pp. 97-120). Hove, UK: Psychology Press.

Perea, M., \& Lupker, S. J. (2004). Can CANISO activate CASINO? Transposed-letter similarity effects with nonadjacent letter positions. Journal of Memory and Language, 51, 231-246.

Perea, M., \& Pérez, E. (in press). Beyond alphabetic orthographies: The role of form and phonology in transposition effects in Katakana. Language and Cognitive Processes. doi: 10.1080/01690960802053924

Perea, M., \& Pollatsek, A. (1998). The effects of neighborhood frequency in reading and lexical decision. Journal of Experimental Psychology: Human Perception and Performance, 24, 767-779.

Perea, M., \& Rosa, E. (2000). Repetition and form priming interact with neighborhood density at a brief stimulus-onset asynchrony. Psychonomic Bulletin and Review, 7, 668-677.

Perea, M., \& Rosa, E. (2002). Does "whole word shape" play a role in visual word recognition? Perception and Psychophysics, 64, 785-794.

Perea, M., Rosa, E., \& Gómez, C. (2003). Influence of neighborhood size and exposure duration on visual-word recognition: Evidence with the yes/no and the go/no-go lexical decision task. Perception and Psychophysics, 65, 273-286.

Perea, M., Rosa, E., \& Gómez, C. (2005). The frequency effect for pseudowords in the lexical decision task. Perception and Psychophysics, 67, 301-314.

Perry, C., Ziegler, J. C., \& Zorzi, M. (2007). Nested incremental modeling in the development of computational theories: The CDP + model of reading aloud. Psychological Review, 114, 273-315.

Perry, J. R., Lupker, S. J., \& Davis, C. J. (2008). The influence of partial-word primes in a masked prime lexical decision task: An evaluation of the interactive-activation model. Language and Cognitive Processes, 23, 36-68.

Pollatsek, A., Perea, M., \& Binder, K. (1999). The effects of neighborhood size in reading and lexical decision. Journal of Experimental Psychology: Human Perception and Performance, 25, 1142-1158.

Pollatsek, A., Reichle, E. D., \& Rayner, K. (2006). Tests of the E-Z Reader model: Exploring the interface between cognition and eye-movement control. Cognitive Psychology, 52, 1-56.

Pollatsek, A., \& Well, A. (1995). On the use of counterbalanced designs in cognitive research: A suggestion for a better and more powerful analysis. Journal of Experimental Psychology: Learning, Memory, and Cognition, 21, 785-794.

Ratcliff, R. (1981). A theory of order relations in perceptual matching. Psychological Review, 88, 552-572.

Rayner, K. (1998). Eye movements in reading and information processing. Psychological Bulletin, 124, 372-422.

Rayner, K., White, S. J., Johnson, R. L., \& Liversedge, S. P. (2006). Raeding wrods with jubmled lettres: There is a cost. Psychological Science, 17, 192-193.

Reichle, E. D., Pollatsek, A., Fisher, D. L., \& Rayner, K. (1998). Toward a model of eye movement control in reading. Psychological Review, 105, $125-157$.

Schoonbaert, S., \& Grainger, J. (2004). Letter position coding in printed word perception: Effects of repeated and transposed letters. Language and Cognitive Processes, 19, 333-367.

Sears, C. R., Campbell, C. R., \& Lupker, S. J. (2006). Is there a neighborhood frequency effect in English? Evidence from reading and lexical decision. Journal of Experimental Psychology: Human Perception and Performance, 32, 1040-1062.

Sears, C. R., Hino, Y., \& Lupker, S. J. (1995). Neighborhood size and neighborhood frequency effects in word recognition. Journal of Experimental Psychology: Human Perception and Performance, 21, 876-900.

Sears, C. R., Sharp, C. R., \& Lupker, S. J. (2006). Is there a neighborhood frequency effect in English? Evidence from reading and lexical decision. Journal of Experimental Psychology: Human Perception and Performance, 32, 1040-1062.

Siakaluk, P. D., Sears, C. R., \& Lupker, S. J. (2002). Orthographic neighborhood effects in lexical decision: The effects of nonword orthographic neighborhood size. Journal of Experimental Psychology: Human Perception and Performance, 28, 661-681.

Slattery, T. J., Rayner, K., \& Pollatsek, A. (2007, November). Neighbor frequency effects in English: Parallels with lexical ambiguity resolution? Poster presented at the 48th Annual Meeting of the Psychonomic Society, Long Beach, CA.

Smith, P. T., Jordan, T. R., \& Sharma, D. (1991). A connectionist model of visual-word recognition that accounts for interactions between mask size and word length. Psychological Research, 53, 80-87.

Stadthagen-Gonzalez, H., \& Davis, C. J. (2006). The Bristol norms for age of acquisition, imageability and familiarity. Behavior Research Methods, 38, 598-605.

Tegner, R., \& Levander, M. (1993). Word length coding in neglect dyslexia. Neuropsychologia, 31, 1217-1223.

Van Assche, E., \& Grainger, J. (2006). A study of relative-position priming with superset primes. Journal of Experimental Psychology: Learning, Memory, and Cognition, 32, 399-415.

Welvaert, M., Farioli, F., \& Grainger, J. (2008). Graded effects of number of inserted letters in superset priming. Experimental Psychology, 55, 54-63.

Whitney, C. (2001). How the brain encodes the order of letters in a printed word: The SERIOL model and selective literature review. Psychonomic Bulletin and Review, 8, 221-243.

Whitney, C. (2004). Investigations into the neural basis of structured representations. Unpublished Doctoral Dissertation, University of Maryland, College Park. Available in electronic form at http:// www.cs.umd.edu/ shankar/cwhitney/diss_final.pdf

Whitney, C. (2008). A comparison of the SERIOL and SOLAR theories of letter-position encoding. Brain and Language, 107, 170-178.

Whitney, C., \& Berndt, R. S. (1999). A new model of letter string encoding: Simulating right neglect dyslexia. In J. A. Reggia, E. Ruppin, \& D. Glanzman (Eds.), Progress in brain research (Vol. 121, pp. 143-163). Amsterdam: Elsevier. 
Williams, C. C., Perea, M., Polltasek, A., \& Rayner, K. (2006). Previewing the neighborhood: The role of orthographic neighbors as parafoveal previews in reading. Journal of Experimental Psychology: Human Perception and Performance, 32, 1072-1082.
Zorzi, M., Houghton, G., \& Butterworth, B. (1998). Two routes or one in reading aloud? A connectionist dual-process model. Journal of Experimental Psychology: Human Perception and Performance, 24, 11311161.

Appendix

\section{Words Used in Experiment 1}

Note. The words are presented in triads: word with higherfrequency DNs, the corresponding control word, and (in parentheses) the higher-frequency DN.

Initial overlap. desdén; estrés; (desde).cortés; verbal; (corte).serial; turrón; (seria).clavel; vibrar; (clave).clímax; cactus; (clima).soldador; trapecio; (soldado).ciclón; rencor; (ciclo).anchoa; acelga; (ancho).bloqueo; estuche; (bloque).operar; asomar; (ópera).armador; budista; (armado).estelar; fósforo; (estela).tenaza; fabada; (tenaz).saqueo; ruleta; (saque).nominal; egipcio; (nómina).guiñol; faisán; (guiño).atracón; jaqueca; (atraco).consolar; inyectar; (consola).propinar; rebuznar; (propina).selector; chubasco; (selecto).

Final overlap. erizado; titubeo; (rizado).calambre; rumiante; (alambre).clavar; gruñir; (lavar).goleada; esófago; (oleada).anguila; soprano; (águila).frígida; enchufe; (rígida).aguante; acequia; (guante).relevar; repeler; (elevar).remitir; ingerir; (emitir).utópico; azafata; (tópico).jarabe; novato; (árabe).atraer; exigir; (traer).sacudir; incidir; (acudir).linterna; pabellón; (interna).ahogar; educar; (hogar).aversión; cerámica; (versión).mandar; situar; (andar).apagar; evento; (pagar).aprecio; tolerar; (precio).patentar; exportar; (atentar).

Outer overlap. obseso; bufete; (obeso).granuja; cotorra; (granja).cósmico; rústico; (cómico).fractura; diagonal; (factura).absorto; pupitre; (aborto).alternar; colmillo; (alterar).trauma; jazmín; (trama).estigma; sortija; (estima).camisón; esgrima; (camión).hervida; tatuaje; (herida).indicio; limosna; (inicio).orégano; amuleto; (órgano).carnal; franja; (canal).étnica; enfado; (ética).flecha; nervio; (fecha).constar; sembrar; (contar).madrina; padrino; (marina).desatino; sinagoga; (destino).juzgar; vestir; (jugar).asfalto; lateral; (asalto).

\section{Nonword Used in Experiment 1}

Note. The nonwords are presented in triads: nonword with a $\mathrm{DN}$, the corresponding control nonword, and (in parentheses) the base word for the experimental nonword.

Initial overlap. sonidol; lenirol; (sonido). debatel; pematel; (debate). juevesa; bueresa; (jueves). camisal; marosil; (camisa). minutor; tecader; (minuto). poesiar; foeniar; (poesía). fiscalo; distabo; (fiscal). premiol; dresiol; (premio). vecinor; mebinor; (vecino). alientor; emientor; (aliento). canciona; rentioma; (canción). detallel; semallel; (detalle). suavel; buamel; (suave). débile; pétime; (débil). hielor; miacor; (hielo). legale; mefade; (legal). noviar; puviar; (novia). tratol; prapil; (trato). dulcer; sencal; (dulce). tesiso; seciso; (tesis).

Final overlap. bescala; cistata; (escala). clejano; blegino; (lejano). frápida; frecuda; (rápida). cempleo; bompreo; (empleo). fíndice; lántoce; (índice). grelato; creleto; (relato). ocerrar; aborrer; (cerrar). samplio; cemblio; (amplio). apágina; arósina; (página). abotella; ameralla; (botella). bagencia; dogercia; (agencia). gradical; bretical; (radical). achina; achama; (china). aplato; oprito; (plato). cletra; blatra; (letra). breino; breiso; (reino). alíder; adácer; (líder). pajeno; saceto; (ajeno). dética; sébima; (ética). oconde; onento; (conde).

Outer overlap. amanate; abonote; (amante). compira; dompusa; (compra). elegrir; obagrir; (elegir). enterla; asdinta; (entera). forumar; baledir; (formar). olvindo; asvinda; (olvido). oscurta; asmerta; (oscura). patoria; bemesia; (patria). serovir; suredar; (servir). curinoso; merivoso; (curioso). ablogado; acoberna; (interna). vilernes; milurnos; (viernes). cielgo; bieldo; (ciego). flirma; crasme; (firma). meturo; caturo; (metro). juslio; sasmio; (julio). viudra; siubra; (viuda). rubiso; saboma; (rubio). moltor; diltor; (motor). priano; groino; (piano).

\section{Words Used in Experiment 2}

Note. The words are presented in triads: word with higherfrequency ANs, the corresponding control word, and (in parentheses) the higher-frequency AN.

Final overlap. astilla; alpiste; (castilla). enero; héroe; (género). astro; misil; (rastro). estante; brújula; (restante). andado; esbozo; (mandado). errado; retoño; (cerrado). robar; cutis; (probar). impío; boxeo; (limpio). robado; relevo; (probado). visado; víbora; (avisado). ducado; nocivo; (educado). nuncio; rambla; (anuncio). atinar; jadear; (patinar). reparar; montaje; (preparar). oloroso; teorema; (doloroso). residir; atisbar; (presidir). referir; debatir; (preferir). estival; injerto; (festival). imitada; arenoso; (limitada).

Outer overlap. fiado; trufa; (fijado). senado; escudo; (sentado). conejo; arroyo; (consejo). sobrio; jazmín; (sobrino). alcázar; cepillo; (alcanzar). visera; fabada; (víspera). realzar; embalse; (realizar). logia; dátil; (lógica). pasaje; butaca; (paisaje). mítica; cohete; (mística). eslavo; roedor; (esclavo). babero; nuboso; (barbero). menaje; orfeón; (mensaje). cliente; castigo; (caliente). violeta; insecto; (violenta). planear; asustar; (plantear). inmoral; gaviota; (inmortal). pródigo; enchufe; (prodigio). cocción; soprano; (coacción).

\section{Nonwords Used in Experiment 2}

Note. The nonwords are presented in triads: nonword with an $\mathrm{AN}$, the corresponding control nonword, and (in parentheses) the base word for the experimental nonword.

Initial overlap. futbo; musbe; (fútbol). poesi; soeri; (poesía). azuca; omasi; (azúcar). higad; hodad; (hígado). rechaz; michor; (iglesia). pañuel; losuel; (rechazo). actitu; octati; (actitud). ajedre; ugadro; (ajedrez). terraz; corriz; (terraza). suicid; ulcado; (alcohol). cadave; malode; (cadáver). socieda; puriesa; (sociedad). varieda; masiodad; (variedad). volunta; lugirta; (voluntad). superio; zejería; 
(superior). aventur; omintar; (aventura). singula; solmute; (singular). criatur; briaper; (criatura). asamble; osumpre; (asamblea).

Final overlap. erfil; osdil; (perfil). nidad; pudad; (unidad). ítulo; ífuro; (título). irgen; osgan; (virgen). espués; ascaés; (después). entido; orbedo; (sentido). róximo; rébura; (próximo). elleza; ollosa; (belleza). eligro; omabro; (peligro). oticia; ubesia; (noticia). urante; ocisto; (durante). obierno; edierma; (gobierno). roblema; riplemo; (problema). ilencio; odencia; (silencio). royecto; rilesto; (proyecto). ompañía; astidía; (compañía). iscurso; ospurca; (discurso). arácter; omistor; (carácter). rofesor; domiror; (profesor).

Outer overlap. cidad; badad; (ciudad). pruba; plade; (prueba). sange; punve; (sangre). dercho; mircho; (derecho). enome; adugo; (enorme). conumo; lomeno; (consumo). ciecia; puecia; (ciencia). céped; ruped; (cesped). enfemo; undesa; (enfermo). sonisa; posuro; (sonrisa). crital; crosel; (cristal). mietras; loapres; (mientras). nosotos; modatos; (nosotros). libetad; lobidad; (libertad). pelíula; potíura; (película). esfurzo; anburma; (esfuerzo). minitro; cimubro; (ministro). econmía; opunmía; (economía). juvetud; gobadad; (juventud).

\section{Words Used in Experiment 3}

Note. The words are presented in triads: word with higherfrequency ANs, the corresponding control word, and (in parentheses) the higher-frequency AN. Words marked with an asterisk were excluded from the analyses due to high error rates.

Final overlap. Anger; uncle; (danger). Arrow; blunt (narrow). Broad; skill (abroad). Error; essay (terror). Inner; blind (winner). Lease; drown (please). Lever; stall (clever). Mount; pause (amount). Ranch; gleam (branch). Refer; alert (prefer). Scent; cease (ascent). Truck; skirt (struck). Utter; vivid (butter). Venue; brute (avenue). Witch; linen (switch).

Outer overlap. beast; belly (breast). Caste*; haste (castle). Ether*;

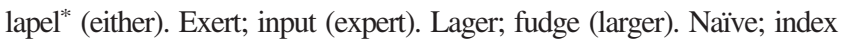
(native). Petty; lousy (pretty). Phase; eager (phrase). Pubic; shrug (public). Purse; stool (pursue). Resin; plaza (resign). Salon; bison* (saloon). Sprig*; expel (spring). Stain; stall (strain). Stale; mound (stable). Stoke; chink ${ }^{*}$ (stroke). Super; weird; supper. Surly; sonic (surely). Tough; shift (though). Tread; blend (thread). Treat; drunk (threat). Widow; fluid ](window).

Initial overlap. bough*; abode* (bought). Brand; brisk (brandy). Forgo*; prune* (forgot). Rabbi; venom (rabbit). Sever; hover (severe). Whisk; jewel (whisky).

\section{Nonwords Used in Experiment 3}

Note. The nonwords are presented in groups of six in the following order: nonword with an initial overlap AN, the corresponding control nonword, nonword with a final overlap AN, the corresponding control nonword, nonword with an outer overlap AN, the corresponding control nonword, and (in parentheses) the base word for the experimental nonword.

wisdo, wisto, isdom, istom, wisom, wirom (wisdom).

bisho, bislo, ishop, eshop, bisop, bilop (bishop). victi, vacti, ictim, ictam, vitim, vatim (victim). seldo, saldo, eldom, eldam, sedom, senom (seldom). targe, tarme, arget, arbet, taget, tuget (target). signa, sigha, ignal, ignad, sigal, sogal (signal). profi, prafi, rofit, ropit, proit, ploit (profit). stupi, shupi, tupid, tupad, stuid, stuad (stupid). deser, desor, esert, elert, deert, deern (desert). credi, cledi, redit, renit, creit, cleit (credit). murde, marde, urder, urber, muder, fuder (murder). plent, plunt, lenty, lunty, plety, plegy (plenty). silen, siben, ilent, ilert, sient, soent (silent). memor, mecor, emory, emony, meory, geory (memory). thirt, thilt, hirty, hilty, thity, thoty (thirty). secre, sedre, ecret, ecrat, secet, sacet (secret). famil, fabil, amily, aminy, faily, taily (family). docto, dosto, octor, ostor, dotor, dobor (doctor). churc, chulc, hurch, herch, chuch, chach (church). momen, moken, oment, olent, moent, moend (moment). secon, sacon, econd, ecand, seond, saond (silry). salar, sular, alary, alart, salry, silry (salary). luxur, laxur, uxury, uxory, luxry, lexry (luxury). junio, juneo, unior, uniol, junor, jinor (junior). cousi, coudi, ousin, oumin, cosin, cosan (cousin). healt, mealt, ealth, eanth, halth, hilth (health). weapo, weado, eapon, eanon, wapon, wadon (weapon). mutua, mutia, utual, uvual, mutal, mudal (mutual). museu, museo, useum, aseum, musum, musup (museum). ritua, ridua, itual, etual, rital, natal (ritual). honou, hinou, onour, onoar, honur, fonur (honour). geniu, ganiu, enius, enias, gnius, gniud. (genius). belon, bilon, elong, ilong, blong, blorg (belong). spiri, spori, pirit, pimit, sprit, spret (spirit). sprea, splea, pread, proad, sprad, spril (spread). theor, thaor, heory, weory, thory, thary (theory). merel, mesel, erely, enely, merly, murly (merely). beyon, beyan, eyond, eyand, beynd, beynk (beyond). direc, dinec, irect, irelt, drect, dreft (direct). labou, laboa, abour, aboul, labur, lavur (labour). schoo, scloo, chool, choom, schol, schom (school). shoul, shoil, hould, pould, shuld, chuld (should).

\section{Sentences Used in Experiment 4}

Note. The words used in the experiment appear in parentheses. The word with a higher-frequency (deletion/addition) neighbor is listed first. The word in italics enclosed by parentheses at the end of the sentences is the higher-frequency neighbors of the first member of the pair.

Aquello ya quedó (fiado, añejo) y no supimos más. (fijado)

Si esto es (fiado, añejo) no lo aceptaremos.

Figurar en el (senado, remite) le hace ilusión. (sentado)

El cambio de (senado, remite) era necesario.

Vas a tener (conejo, cuñada) hasta hartarte. (consejo)

Si no hay (conejo, cuñada), no hay comida familiar. 
Es un chico (sobrio, hebreo) el que nos atiende en la tienda. (sobrino)

El arte estilo (sobrio, hebreo) no me atrae nada.

Tener un bonito (alcázar, abdomen) exige mucho tiempo. (alcanzar)

Tras ver el (alcázar, abdomen), el experto opinó.

Marcos compró una (visera, rebeca) a su hermana. (víspera)

Marta cogió la (visera, rebeca) para salir a pasear.

Es mi consejo: (realzar, vueltos) los calcetines da un toque de estilo. (realizar)

Esa oración de (realzar, vueltos) al Señor me la sé desde pequeñito.

Nos aprendimos el (pasaje, léxico) entero para pasar al segundo curso. (paisaje)

Memorizar todo el (pasaje, léxico) no tiene sentido si no comprendes nada.

Es un poco (mítica, pasivo) pero me gusta. (mística)

$\mathrm{Su}$ status de (mítica, pasivo) no ayuda a tomar decisiones en el grupo.

El desconocido joven (eslavo, alevín) que fichamos juega muy bien. (esclavo)

El nuevo equipo (eslavo, alevín) va el primero esta temporada.

El niño agarró el (babero, pitufo) mientras tomaba el potito. (barbero)

Daniel recibió un (babero, pitufo) como regalo en su cumpleaños.

Nos desharemos del (menaje, latoso) y nos iremos de aquí. (mensaje)

Tenemos en casa un (menaje, latoso) que nos hace la vida incómoda.

Es necesario tener (cliente, treinta) para poder ascender. (caliente)

$\mathrm{Si}$ ya tienes (cliente, treinta) entras en la empresa de comercial.

El espacio (violeta, viajado) me impresionó mucho. (violenta)

El tramo (violeta, viajado) al anochecer es mi mejor recuerdo.

La dificultad es (planear, gradual) y eso requiere organización. (plantear)

El objetivo será (planear, gradual) y tendremos un plazo de un año.

Yo creo que (inmoral, acritud) es un término descriptivo. (inmortal)

Se calificó como (inmoral, acritud) su conducta de anoche.

El joven chico (pródigo, plebeyo) acabó siendo el dueño de las tierras. (prodigio)

Con su hijo (pródigo, plebeyo) el padre se sentía feliz.

Para una mejor (cocción, succión) pon la leche en otro recipiente. (coacción)

Puedes evitar la (cocción, succión) del jugo y disfrutar del sabor.

Visitamos la antigua (galera, bolera) en la excursión de la catequesis. (galería)

Entrar a la (galera, bolera) cuesta cinco euros.

Saber vivir sin (sueldo, siesta) es posible, te lo digo yo. (suelo)

Dime si con (sueldo, siesta) uno vive mejor y es más feliz.

No hay que (juzgar, vestir) como lo hacen los demás. (jugar)

Es más fácil (juzgar, vestir) a otro que a uno mismo.

Fíjate en la (cualidad, suavidad) y no en otros aspectos del regalo. (calidad)

Al final la (cualidad, suavidad) es lo que nos hizo decantarnos.
Se definía como (carnal, cónsul), pero nadie lo creyó. (canal)

Tu marido será (carnal, cónsul) pero el mío es romántico y sencillo.

Basándonos en tu (indicio, astucia) llegaremos hasta el asesino. (inicio)

Fíate de tu (indicio, astucia) y sigue adelante con la investigación.

Sorprendió con su (sigilo, cocido) cuando llegó a casa. (siglo)

Por entrar sin (sigilo, cocido) le echaron de la cena.

Si sales con (camisón, tacones) a la calle yo no voy contigo. (camión)

Al verla sin (camisón, tacones) me llevé una gran decepción.

Pedro estaba muy (absorto, inmerso) en su faena cuando lo interrumpimos. (aborto)

Si sigues tan (absorto, inmerso) en el trabajo, te dolerá la cabeza.

El de la (flecha, brecha) es el indio malo. (fecha)

Me pinté una (flecha, brecha) en la cabeza para carnaval.

Ana tocó la (fractura, glándula) y gritó de dolor. (factura)

Tratamientos para la (fractura, glándula) a no hay muchos.

No puedes hacer (constar, sembrar) esto. (contar)

Hay que hacer (constar, sembrar) lo que tenemos aquí.

En combate, el (trauma, croata) fue terrible. (trama)

Debido a un (trauma, croata) he llegado hasta aquí.

La rica diversidad (étnica, gitana) es una realidad social. (ética)

La nueva identidad (étnica, gitana) es el tema de hoy.

Ayer hablamos del (estigma, establo) y no llegamos a ningún acuerdo. (estima)

El tema del (estigma, establo) o ya está zanjado.

Tiene un toque (cósmico, rústico) ese salón, que no me gusta. (cómico)

Visitamos el espacio (cósmico, rústico) del museo.

Los padres deben (alternar, envolver) al bebé para darle seguridad. (alterar)

Nos obligaron a (alternar, envolver) los regalos para la subasta.

Me parece un (desatino, desacato) que se presente así en tu casa. (destino)

Cometió un gran (desatino, desacato) y ahora está pagando por ello.

Creamos un mundo (obseso, impuro) y preocupado por lo efímero. (obeso)

Lo superficial hace (obseso, impuro) al hombre actual.

El jugador está (pasmado, fichado) y no juega nada bien. (pasado)

El ladrón quedó (pasmado, fichado) tras ser atrapado por la policía.

Este tipo de (orégano, ovejero) se aprecia en zonas rurales. (órgano)

Tú conoces el (orégano, ovejero) porque vives en el campo.

Toda la ropa (hervida, holgada) era inservible. (herida)

Una pequeña gasa (hervida, holgada) sobre la quemadura será útil.

El pastor es (sureño, cateto) y vive aislado. (sueño)

Ese tipo tan (sureño, cateto) tiene mucho acento.

Este niño tan (granuja, crédulo) lo pasara mal. (granja)

Received February 1, 2008

Revision received July 21, 2008

Accepted September 4, 2008 